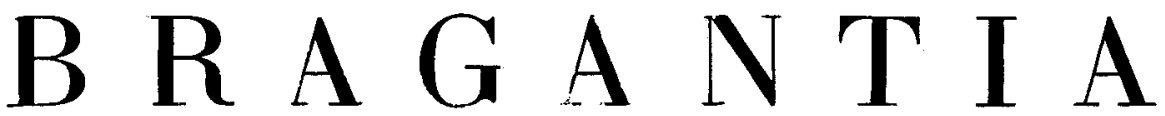

Boletim Científico do Instituto Agronômico do Estado de S. Paulc

Vol. 27

Campinas, setembro de 1968

N. ${ }^{\circ} 28$

\title{
OBTENÇÃO DE VARIEDADES DE PIMENTÃO RESISTENTES AO MOSAICO $(1,2)$
}

Hiroshi Nagar, engenheiro-agrônomo, Seção de Virologia, Instituto Agronômico

\section{SINOPSE}

Tendo em vista as perdas consideráveis causadas pela moléstia conhecida como "mosaico do pimentão", induzida por estirpes do vírus Y da batatinha, nas culturas de pimentão (Capsicum annuum L.), formulou-se um projeto visando criar variedades resistentes.

Como fontes de resistência, cêrca de 45 introduções de pimentão e $4 C$ de pimenteiras, compreendendo oito espécies do gểnero Capsicum, foram submetidas aos testes de inoculação.

Três novos fatôres genéticos responsáveis pela resistência aos grupos $\mathrm{n}$ e $\mathrm{w}$ do virus $\mathrm{Y}$ foram encontrados em certas variedades de $\mathbf{C}$. annuum: GENe "H": dominante, encontrado nas variedades Casca Dura e Mogi das Cruzes, que condiciona reação de hipersensibilidade ao vírus $\mathrm{Yn}^{\mathrm{n}}$.

GENE "w": recessivo, que controla a tolerância da var. Pôrto Rico Wonder ao vírus $\mathrm{Yw}$.

GENE "f": recessivo, que condiciona a tolerância ao virus Yf na var. Noura. Há indicação de alelismo entre os genes "w" e "f", sendo que o nivel de tolerância dêste é mais elevado que o daquele.

A imunidade ao vírus $\mathrm{Y}$ constatada em $\mathrm{P} 11$ (P. I. 264281), cujo comportamento foi atribuído à ação de um par de genes recessivos "ya", foi confirmada também com relação às estirpes do vírus $Y$ que aqui ecorrem.

As combinaçōes de tôdas as fontes de resistência acima citadas possibilitaram a criação de novas variedades de pimentão pràticamente imunes ao vírus $\mathrm{Y}$, bastante produtivas e com caracteristicas comerciais satisfatórias. Agronômico 7 produz frutos quadrados (tipo California Wonder) e Agronômico 8 apresenta frutos cônico-alongados (tipo Casca Dura).

( $\left.{ }^{1}\right)$ Tese de doutoramento apresentada à Escola Superior de Agricultura "Luiz de Queiroz", da Universidade de São Paulo, em agôsto de 1967. Recebido para publicação em 20 de outubro de 1967.

( $\left.{ }^{2}\right)$ Trabalho parcialmente subvencionado pelo Conselho Nacional de Pesquisas. 


\section{1 - INTRODUÇÃO}

Entre as moléstias que afetam o pimentão (Capsicum annuum L.) destacam-se aquelas causadas por vírus. De fato, as viroses podem constituir fator limitante da produção desta cultura. Das plantações naturalmente infetadas têm sido isolados: o vírus $Y$ da batatinha (potato virus $\mathrm{Y}$ ); $\mathrm{o}$ vírus do mosaico comum do fumo (tobacco mosaic virus); o vírus de vira-cabeça (tomato spotted-wilt virus); o vírus do amarelo do pimentão (tomato curly-top virus); e o vírus do tôpo amarelo do tomateiro (potato leafroll virus). $O$ vírus $Y$, o mais destrutivo e o mais prevalecente, é o agente causal da moléstia conhecida pelo nome de "mosaico do pimentão" (pepper mosaic virus ou pepper vein-banding virus) $(1,9,10,11,12,21,23,24,25,26,28)$. Este vírus é disseminado na natureza por afídios, especialmente Myaus persicae Sulz., e para o seu contrôle recomenda-se a destruição dos insetos vectores por meio da aplicação de inseticidas. Tal medida, entretanto, mesmo executada desde a fase inicial da cultura, não se tem mostrado eficiente na prática da nossa lavoura.

Face às dificuldades observadas no contrôle do mosaico do pimentão por meio de tratos culturais acessiveis ao lavrador, necessário se tornou lançar mão de um plano visando incorporar resistência ao mosaico, no pimentão.

O presente trabalho apresenta as informações obtidas no estudo de viroses do pimentão causadas pelas estirpes do vírus $Y$, variabilidade dos patógenos e diversidade das reações varietais, e indica sucintamente os processos usados na obtenção de variedades resistentes ao mosaico.

\section{2 - MATERIAL E MÉTODOS}

O presente trabalho foi realizado na Seção de Virologia, do Instituto Agronômico de Campinas, Estado de São Paulo, entre 1961 e 1967.

\section{1 - AGENTE CAUSAL DO MOSAICO DO PIMENTÃO}

Os vários isolados do vírus $\mathrm{Y}$ da batatinha que afetam $\mathrm{o}$ pimentão e a pimenteira em São Paulo podem ser colocados em đois grupos principais, designados por grupo $\mathbf{n}$ e grupo w, na Seção de Virologia. 


\subsection{1 - GRUPO N DO VfRUS Y DA BATATINHA}

Além das características morfológicas (19) e propriedades físicas que identificam como vírus $\mathrm{Y}$, as estirpes dêste grupo apresentam peculiar tendência para causar lesōes locais pequenas e numerosas nas fôlhas de Nicandra physaloides Gaertn. (ESTAMPA 1-B). Nas plantas do fumo (Nicotiana tabacum L.) var. TNN (variedade Turkish, na qual foram incorporados os genes "NN" em homozigose), o vírus causa palidez das nervuras e posteriormente faixa-das-nervuras. Sob condições naturais, êste grupo do vírus $\mathrm{Y}$ nāo afeta o tomateiro e nem a batatinha.

Plantas afetadas de pimentão sofrem acentuada redução no crescimento. Os sintomas que mais caracterizam a moléstia são mosqueamento e encarquilhamento das fôlhas. O mosqueamento pode ser de padrões diversos, desde manchas grandes até salpicos (ESTAMPA 1-A). Os frutos produzidos pelas plantas afetadas pelo mosaico podem ser menores que os normais. Apesar de a sua incidência ser baixa, a distribuição é bastante extensa, tendo sido coletado nas regiões noroeste, litoral-sul e nas proximidades da capital do Estado (Mogi das Cruzes, principalmente) e na Baixada Fluminense.

Entre isolados, foi usado nas investigaçōes o vírus denominado "Yn-coleção", por apresentar características típicas do grupo com mais nitidez.

\section{$2.1 .2 \rightarrow$ GRUPO W DO VIRUS Y DA BATATINHA}

Ėste grupo do vírus $\mathrm{Y}$ é o responsável pela importante virose do tomateiro, conhecida pelo nome de "risca do tomateiro" (11) (ESTAMPA 1-C), e, ao mesmo tempo, o principal agente causal do mosaico do pimentão. A sua ocorrência é generalizada, e segundo levantamentos efetuados, cada vez mais freqüente no Estado de São Paulo e nos Estados vizinhos, onde o vírus vem constituindo grave problema nas lavouras de hortaliças.

Pertencem a êsse grupo a estirpe denominada $\mathrm{Y}^{\mathrm{w}}$, causadora de murchamento no fumo como sua principal caracteristica, e a estirpe $\mathrm{Y}^{\mathrm{f}}$, que é mais severa do que a anterior ao pimentão e ao tomateiro.

Os sintomas apresentados pelas variedades suscetíveis de pimentão a êste grupo do vírus, tanto de $\mathrm{Y}^{\mathrm{w}}$ como de $\mathrm{Y}^{\mathrm{f}}$, são bastante semelhantes aos sintomas causados pelas estirpes do 
grupo anterior. Plantas afetadas são enfezadas e não produzem frutos de boa qualidade. Os sintomas foliares são comparativamente com o vírus $\mathrm{Y}^{\mathrm{n}}$ mais conspicuos, apresentando faixas escuras ao longo das nervuras e encarquilhamento mais acentuado.

Após o surto da estirpe $\mathrm{Y}^{\mathrm{f}}$, ocorrido em larga escala por volta de 1963, o grupo $\mathrm{w}$ passou a ser representado pela estirpe $\mathrm{f}$ no trabalho de criação de variedades resistentes ao mosaico, apesar de a estirpe $\mathrm{Y}^{\mathrm{w}}$ continuar sendo encontrada com certa freqüência nas plantações de pimentão e de tomateiro.

\section{2 - PROCEDÊNCIA DAS VARIEDADES EMPREGADAS}

As seguintes variedades de pimentão e pimenteira foram testadas quanto à resistência aos vírus causadores do mosaico do pimentão.

Para distinguir pimentão de pimenta, adotou-se o critério prático e simples de verificar a ocorrência de ardume no fruto, o qual é devido à presença da capsaicina $\left(\mathrm{C}_{18} \mathrm{H}_{27} \mathrm{NO}_{3}\right)$.

\section{VARIEDADES}

PIMENTÃO (C. annuUm)

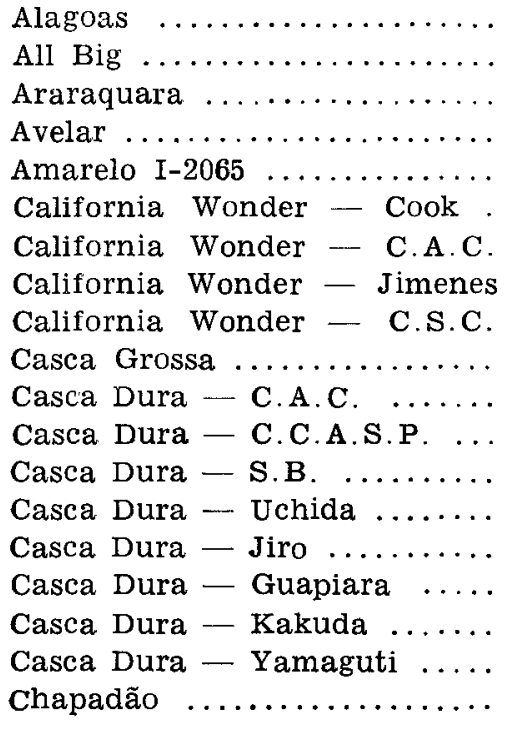

Pilar (AL)

C.A.C. - Ferry Morse Araraquara (SP) Avelar (RJ) - I.P.E.A.C.S. Seção de Olericultura IAC Dr. A. A. Cook C.A.C. Casa de sementes Jimenes, Campinas Crosman Seed Co. C.C.A.S.P. C.A.C. C.C.A.S.P. C.C.A.S.B. Campinas (SP) Andradas (MG) Guapiara (SP) Capão Bonito (SP)

Campinas (SP) Campinas (SP) 
(Continuação)

VARIEDADES

Chifre-de-boi

Doce da Espanha - Jimenes

Doce da Espanha ............

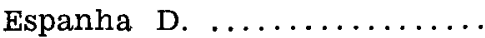

Formosa

Gigante chinês

Ikeda (Ide)

Itapetininga $\ldots \ldots \ldots \ldots \ldots \ldots$

Jundiaí $\ldots \ldots \ldots \ldots \ldots \ldots \ldots$

Kongo .....................

Mamouth .................

Mogi das Cruzes I-2199 .....

Monstruoso ................

Moura

Paulista

Pôrto Rico Wonder I-1799 ....

Ruby King - C.A.C. ........

Ruby King ................

Shimabukuro

Vermelho

World Beater I-486

World Beater - C.A.C. ....

Yolo Wonder I-2095 ..........

Yolo Wonder -. C.A.C. ......

Yolo Wonder - C.S.C. ......

YRP 10

\section{Pimenteiras}

\section{C. annuum}

CV $2-1-2-1 \ldots \ldots \ldots \ldots \ldots \ldots$.

CV 2-1-2-2 .................

Ac. 635

SA 427

SA 59

P 11 (P.I. 264281) ...........

P $11-4 \ldots \ldots \ldots \ldots \ldots . . . .$.

S. C. 46252 (P 34) $\ldots \ldots \ldots \ldots$

I -30764

\section{Procedência ou local de coleta}

São Carlos (SP)

Casa de sementes Jimenes, Campinas

Casa de sementes O. Felipe, Campinas

Dierberger Agro-Comercial Ltda.

Ilha Formosa - Sec. Introdução IAC

Casa de sementes Jimenes, Campinas

Campinas (SP)

Casa da Lavoura, Itapetininga (SP)

Coop. Agricola de Campinas

Musashi, Japão

Dierberger Agro-Comercial Ltda.

Seção de Olericultura IAC

Dierberger Agro-Comercial Ltda.

Campo Grande (GB) - Dr. C. F. Robbs

Mercado de São Paulo

Dr. M. Dias - Sec. Olericultura IAC C.A.C.

Casa de sementes Jimenes, Campinas

Campinas (SP)

Campinas (SP)

Seção de Olericultura IAC

C.A.C.

Seção de Olericultura IAC

C.A.C.

Crosman Seed Co.

Dr. A, A. Cook
Dr. P. G. Smith

Dr. P. G. Smith

México - Dr. P. G. Smith

Louisiana (E.U.A.) - Dr. P. G. Smith

Colômbia - Dr. P. G. Smith

Dr. A. A. Cook

Dr. A. A. Cook

Dr. A. A. Cook

México - Seção de Introdução IAC 
(Continuação)

VARIEDADES

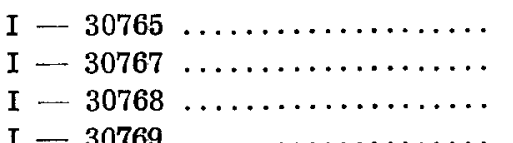

C. pubescens

SA 54

SA 112

SA 266

C. praetermissum

SA 221

C. chacoense

SA 425

SA 347

C. sinense

SA 366

SA 260

SA 397

C. frutescens

SA 25-1-3

SA 25-1-5

C. microcarpum

SA 203

SA 287

\section{C. pendulum}

SA 208

SA 191

I-30771

I-30772

Pimenta comprida
Procedência ou local de coleta

México - Seção de Introdução IAC

México - Seção de Introđução IAC

México - Seção de Introdução IAC

México - Seção de Introdução IAC

Colômbia - Dr. P. G. Smith

Equador - Dr. P. G. Smith

Bolívia - Dr. P. G. Smith

Viçosa (MG) - Dr. P. G. Smith

Argentina - Dr. P. G. Smith

Bolívia - Dr. P. G. Smith

Peru - Dr. P. G. Smith

Peru - Dr. P. G. Smith

Peru -- Dr. P. G. Smith

Colômbia - Dr. P. G. Smith

Colômbia - Dr. P. G. Smith

Pôrto Alegre (RS) - Dr. P. G. Smith Bolívia - Dr. P. G. Smith

Pôrto Alegre (RS) - Dr. P. G. Smith Argentina - Dr. P. G. Smith México — Sec. Introđução IAC México - Sec. Introdução IAC Campinas (SP) 
(Continuação)

VARIEDADES Procedencia ou local de coleta

Capsicum sp.

Ancho A (247) I-3395 $\ldots \ldots$. Seção de Olericultura IAC

Ancho A (1185) I-3396 ...... Seção de Olericultura IAC

Ancho A (1225) I-3399 $\ldots .$. . Seção de Olericultura IAC

Ancho A (1256) I-3401 ..... Seção de Olericultura IAC

Ancho A (1297) I-3400 ..... Seção de Olericultura IAC

Cotaxtla I-3266 ............ Seção de Olericultura IAC

Comari I $-3227 \ldots \ldots \ldots \ldots \ldots$ Seção de Olericultura IAC

Comum I-1158 ............ Seção de Olericultura IAC

Chifre-de-veado I-2757 ..... Seção de Olericultura IAC

Malagueta I-2723 .......... Seção de Olericultura IAC

Mulato M (1908) I-3397 ...... Seção de Olericultura IAC

Pasilla P (9004) I-3398 ...... Seção de Olericultura IAC

I-30773 ................ México - Sec. Introdução IAC

I-30774 ................ México - Sec. Introdução IAC

Obs.: Dr. A. A. Cook - Universidade de Florida E.U.A.

Dr. P. G. Smith - Universidade de California E.U.A.

I.P.E.A.C.S. - Instituto de Pesquisas e Experimentação Agropecuária Centro-Sul M.A.

C.A.C. - Cooperativa Agrícola de Cotia

C.C.A.S.B. - Cooperativa Central Agrícola Sul-Brasil

C.C.A.S.P. - Cooperativa Central Agrícola de São Paulo

\section{3 - TESTES DE RESISTENCIA}

A avaliação do grau de resistência das variedades de pimentão e pimenteira às estirpes $\mathrm{n}, \mathrm{w}$ e $\mathrm{f}$ do vírus $\mathrm{Y}$ e o estudo sôbre a herança dos fatôres genéticos de resistência, bem como as fases iniciais do trabalho de incorporação de resistência, foram efetuados mediante inoculação artificial sob as condições da casa de vegetação. A observação sôbre o comportamento das linhagens derivadas de hibridação e as etapas finais de seleção foram executadas em condições naturais de campo, em diversas partes do Estado e em épocas variadas.

\subsection{1 - INOCULAÇÃO ARTIFICIAL}

Os ensaios de resistência efetuados com inoculação artificial consistiram nos seguintes processos: 
A. Método de inoculação mecânica - Os inóculos foram preparados com as fôlhas de fumo var. TNN recém-infetadas pelo vírus, mostrando sintomas conspícuos. Essas fôlhas foram maceradas em almofariz esterilizado, junto à solução tampão fosfato $0,01 \mathrm{M}$, pH 7 e mais $\mathrm{Na}_{2} \mathrm{SO}_{3}(0,15 \mathrm{~g} / 100 \mathrm{ml})$ como antioxidante, na proporção, em pêso, de 1:5. Quando as fôlhas de pimentão e pimenteira foram fornecedoras do inóculo, a diluiçāo foi aumentada para $1: 20$, devido aos efeitos inibidores característicos do extrato dessas plantas (27). Foi empregado o carborundum (Carbureto de silício), 300 a 400 malhas, como abrasivo, e a inoculação foi feita com o dedo. Pelo menos 40 plantas foram testadas para cada introdução.

B. Avaliação do grau de resistência - O critério sôbre avaliação do grau de resistência ou suscetibilidade obedeceu a uma escala subjetiva, confrontando os sintomas apresentados pelas plantas com diferentes níveis de resistência.

No teste de resistência ao virus $\mathrm{Y}^{\mathrm{n}}$, em que foram constatadas variedades hipersensíveis ou pràticamente imunes, o julgamento das demais variedades suscetiveis não apresentava interêsse para a finalidade dêste trabalho, ao passo que avaliação do grau de resistência aos vírus $\mathrm{Y}^{\mathrm{w}}$ e $\mathrm{Y}^{\mathrm{f}}$ foi importante para a procura da fonte de resistência a êsses vírus. Assim é que os materiais testados com os vírus do grupo $\mathrm{w}$ foram classificados de acôrdo com a seguinte escala: (ESTAMPA 1-D).

ESCALA

Sintomas apresentados pelas plantas

$0 \ldots \ldots$ Imune - A planta é virtualmente imune. O vírus inoculado não é recuperado das plantas.

$1 \ldots .$. ReSistente - Pràticamente não sofre a infecção. Depois das primeiras frutificações um ligeiro mosqueamento principia a aparecer nas fôlhas baixeiras.

$2 \ldots \ldots$ Moderadamente Resistente - Mosqueamento mais conspícuo e generalizado nas fôlhas.

$3 \ldots \ldots$ Moderadamente suscetível - Ligeira redução no porte com forte mosqueamento das fôlhas.

$4 \ldots \ldots$ Muito suscetível - Encarquilhamento das fôlhas e redução sensível do porte. Os frutos podem ser malformados. 
$5 \ldots \ldots$ Extremamente suscetível - Deformação e encarquilhamento das fôlhas. A planta é enfezada e os frutos são diminutos e deformados.

C. Análise estatistica dos resultados - A análise dos fatôres genéticos de resistência foi baseada na segregação das progênies dos cruzamentos e retrocruzamentos. Devido ao fato de os tipos de resistência permitirem identificação das plantas com ou sem fator de resistência, as progênies foram divididas em classes resistente e suscetivel, em confronto com as variedades progenitoras resistentes e suscetíveis.

A segregação $3: 1$ e $1: 1$ foi analisada estatìsticamente pelo teste de $\mathrm{X}^{2}$, aplicando-se as fórmulas simplificadas (13).

Segregação $3: 1$

$$
\mathbf{X}^{2}=\frac{(\mathrm{A}-3 \mathrm{a})^{2}}{3 \mathrm{~N}}
$$

Segregação $1: 1$

$$
\mathbf{X}^{2}=\frac{(\mathrm{A}-\mathbf{a})^{2}}{\mathbf{N}}
$$

onde

$$
\begin{aligned}
& \mathrm{A}=\text { número observado da classe dominante } \\
& \mathrm{a}=\text { número observado da classe recessiva } \\
& \mathrm{N}=\text { número total }
\end{aligned}
$$

A significância foi representada pela probabilidade (valor P).

$$
\text { 2.3.2 - EXPERIMENTOS NO CAMPO }
$$

Os experimentos conduzidos no campo visavam dois objetivos :

a) Seleção de indivíduos com genótipos desejáveis, isto é, plantas resistentes a estirpes mais prevalecentes no campo, numa população segregante. Neste caso, as mudas foram inoculadas com um ou mais vírus dentro da casa de vegetação. Antes do transplante, as mudas foram levadas para fora da casa de vegetação para adquirir necessário endurecimento. No campo, o plantio foi feito com espaçamento amplo, a fim de facilitar a seleção. As pulverizações visavam sòmente o contrôle de vaquinha da batatinha (Epicauta atomaria Germ.). 
b) Observar comportamento das progênies derivadas de hibridação já na fase adiantada de seleção quanto à resistência e às qualidades comerciais, sob conđições naturais de infecção pelos insetos vectores. Os híbridos resistentes foram comparados com as variedades comuns. Quando os ensaios foram realizados na lavoura, êstes foram instalados no meio das plantações comerciais de pimentão, e quando os mesmos materiais foram plantados em diversas localidades, cada local de ensaio foi considerado como uma repetição. Nesses ensaios, as práticas culturais foram as mesmas dispensadas e executadas pelos próprios agricultores.

\section{4 - TÉCNICAS DE HIBRIDAÇÃO}

As polinizações foram efetuadas dentro da casa de vegetação, com as plantas cultivadas em vasos. A emasculação foi feita na fase em que os botões florais se apresentam ainda ligeiramente amarelados. Logo antes da antese, quando os botōes se tornam esbranquiçados e aumentados de tamanho, as anteras já possuem pólen capaz de se desprender com o movimento da flor, na ocasião da emasculação. A coleta de pólen foi feita manualmente, num pequeno vidro, com o auxílio de pinça para sacudir as flores.

Quando as próprias plantas já selecionadas quanto à resistência e quanto às qualidades comerciais precisavam ser usadas como material para cruzamento, dois processos foram empregados para obter pólen, em prazo mais curto que pelo plantio de suas progênies:

a) Poda das plantas à altura da haste secundária, o que forçou brotamento dos ramos e, conseqüentemente, a nova floração.

b) Enxertia das plantas selecionadas sôbre pimentāo ou pimenteira. A enxertia de garfo deu melhor resultado.

\section{3 - RESULTADOS}

Os resultados obtidos referem-se aos estudos sôbre a resistência das variedades representantes do gênero Capsicum às estirpes do vírus $\mathrm{Y}$ e à utilização destas fontes de resistência para a obtenção de híbridos resistentes ao mosaico. 


\section{1 - ESTUdOS SôBRE A RESISTÉNCIA}

Foram estudados aspectos relacionados com a localização de fontes de resistência, tipos de reação e herança dos fatôres genéticos responsáveis pela resistência.

As inoculações foram feitas durante todos os periodos do ano. Não foi observada diferença sensivel na sintomatologia ou na severidade dos sintomas em decorrência da oscilação de temperatura ou outros fatôres climáticos. Nos testes de resistência efetuados dentro da casa de vegetação, os sintomas se manifestaram, ao mais tardar, đuas semanas após a inoculação.

\section{1 .1 - LOCALIZAÇÄO DE FONTES DE RESISTENCIA}

A fim de localizar fontes de resistência aos vírus $\mathrm{Y}^{\mathrm{n}}, \mathrm{Y}^{\mathrm{w}} \mathrm{e}$ $\mathrm{Y}^{\mathrm{f}}$, foram submetidas aos testes de inoculação cêrca de 45 varieclades ou tipos de pimentão e 46 introduçōes de pimenteiras, compreendendo oito espécies do gênero Capsicum.

Os resultados apresentados no quadro 1 foram obtidos nos testes de resistência realizados ao longo de vários anos. Entretanto, o uso de plantas-teste, especialmente a var. Casca Dura C.A.C., como testemunha, e a repetição dos testes permitem estabelecer base para a comparação e avaliação do grau de resistência dêsses materiais, testados sob condições nem sempre idênticas.

A. Fontes de resistência ao virus $Y^{\mathrm{n}}$ - Entre variedades de pimentāo inicialmente testadas em 1961, Casca Grossa e Mogi das Cruzes mostraram reação hipersensivel ao virus $\mathrm{Y}^{\mathrm{n}}$. Embora algumas variedades mais recentemente introduzidas e muitas variedades de pimenteiras mostrassem o mesmo tipo de comportamento, as duas acima citadas serviram como únicas e eficientes fontes de resistência a êste vírus.

Com base nas características vegetativas e reaçōes aos vírus $\mathrm{Y}^{\mathrm{n}}$ e $\mathrm{Y}^{\mathrm{w}}$, a variedade Casca Grossa pode ser considerada idêntica à var. Casca Dura.

B. Fontes de resistência ao virus $Y^{\mathrm{w}}$ - Nos testes iniciais, a var. Pôrto Rico Wonder foi a única que se mostrou resistente ao virus $\mathrm{Y}^{\mathrm{w}}$, e, nesta qualidade, foi usada como fonte de resistência. 
Muitas variedades de pimenteira mostraram-se resistentes, mas $\mathrm{P} 11$ e SC 46252, ambas pertencentes à mesma espécie que 0 pimentão, apresentaram imunidade a êsse vírus. Como $\mathrm{P} 11$ possuia frutos maiores e menos retorcidos que os de SC 46252, aquela variedade foi escolhida para transferência do gene que condiciona a imunidade.

C. Fontes de resistência ao virus $Y^{\mathbf{f}}-\mathrm{O}$ surto da estirpe mais severa foi verificado quando a resistência oferecida pela var. Pôrto Rico Wonder foi vencida no ensaio de campo, onde a var. Moura apresentou alto nivel de resistência à nova variante. Recentemente, a var. Ikeda (Ide) demonstrou alto nivel de resistència ao vírus $\mathrm{Y}^{\mathrm{f}}$, reação esta comparável à da var. Moura. As pimenteiras $\mathrm{P} 11$ e SC 46252 apresentaram imunidade também a êstes vírus. YRP 10 (3) não apresentou resistência às estirpes do vírus $\mathrm{Y}$ que aqui ocorrem.

D. Pimenteiras como fontes de resistência - Com exceção de P 11, P 11-4 e SC 46252, pertencentes a $C$. annuum, não foram encontradas fontes promissoras de resistência ao vírus $\mathrm{Y}$ entre as variedades de pimenteiras testadas. SA 112 (C. pubescens), I-3C771 e I-30772 ( C. pendulum), que se mostraram pràticamente imunes aos vírus $\mathrm{Y}^{\mathrm{n}}$ e $\mathrm{Y}^{\mathrm{w}}$, não foram aproveitadas, pois seriam genèticamente incompativeis com o pimentão $(14,15,29,30,31,32)$.

\section{1 .2 - TIPOS DE RESISTÊNCIA}

Dentro do gênero Capsicum foram observados vários tipos de resistência aos vírus $\mathrm{Y}^{\mathrm{n}}, \mathrm{Y}^{\mathrm{w}}$ e $\mathrm{Y}^{\mathrm{f}}$.

A. Reação ao vírus $Y^{\mathbf{n}}$ - As variedades Casca Dura, Mogi das Cruzes, Avelar e Ikeda (Ide), quando inoculadas mecânicamente com a estirpe $\mathbf{n}$ do vírus $\mathbf{Y}$, geralmente não apresentaram sintomas visíveis e nem a reduçāo do seu crescimento. Muitas variedades de pimenteira também apresentaram o mesmo tipo de reação. No entanto, quando as plantas dessas variedades foram enxertadas sôbre a planta infetada pelo vírus $\mathrm{Y}^{\mathrm{n}}$, provocando invasão contínua do vírus, as plantas passaram a apresentar necroses sistêmicas (Trabalho não publicado). Raramente as fôlhas podem apresentar lesōes locais. Êstes fatos indicam que a resistência ao vírus $\mathrm{Y}^{\mathrm{n}}$ apresentada por essas variedades de pimentão pode ser do tipo denominado "hipersensibilidade". 
QuAdro 1. - Graus de resistência às três estirpes do vírus $\mathrm{Y}$, apresentados por variedades de pimentão e pimenteira, por meio de testes de inoculação dentro da casa de vegetação, em Campinas (SP)

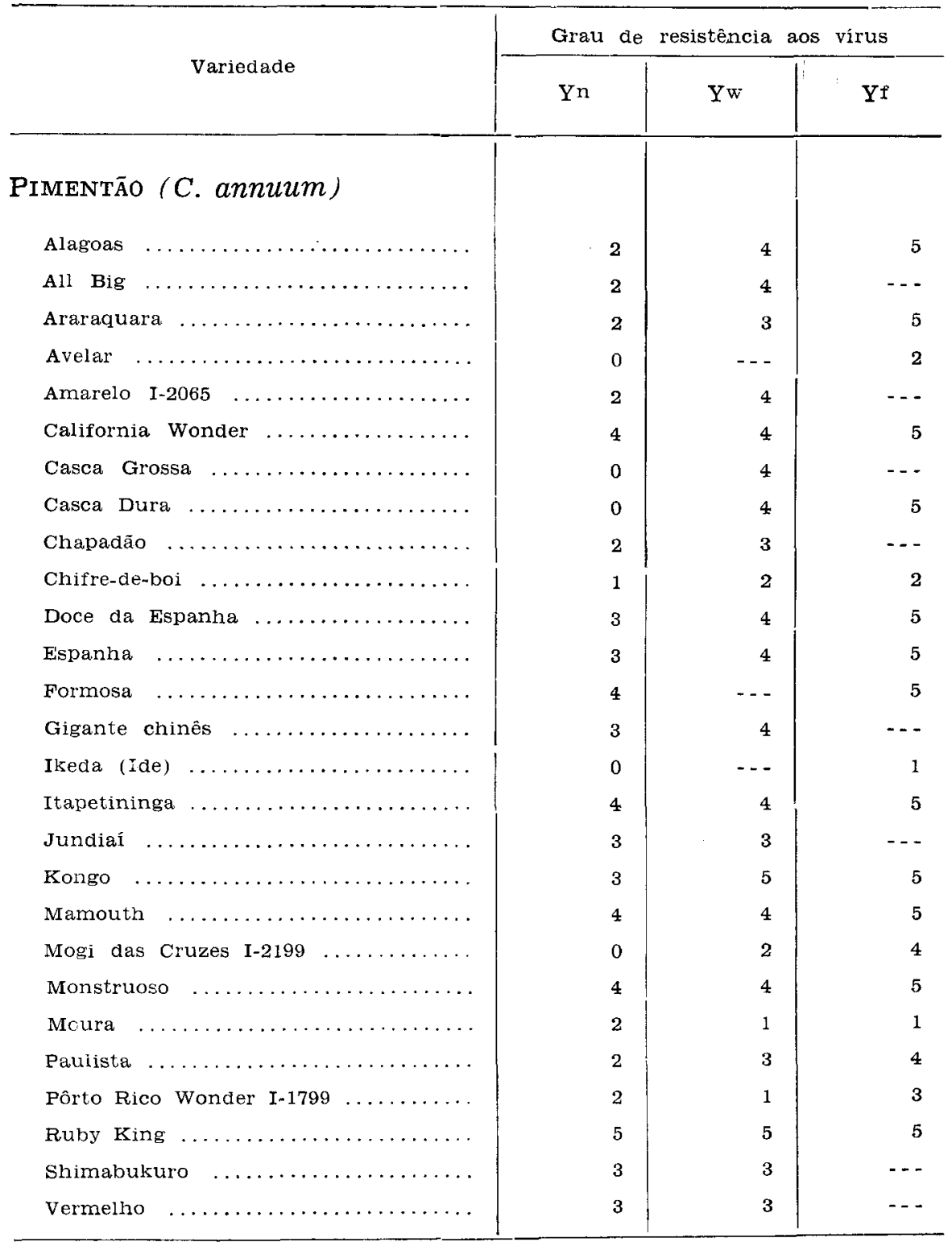


QUADRo 1. - (Continuação)

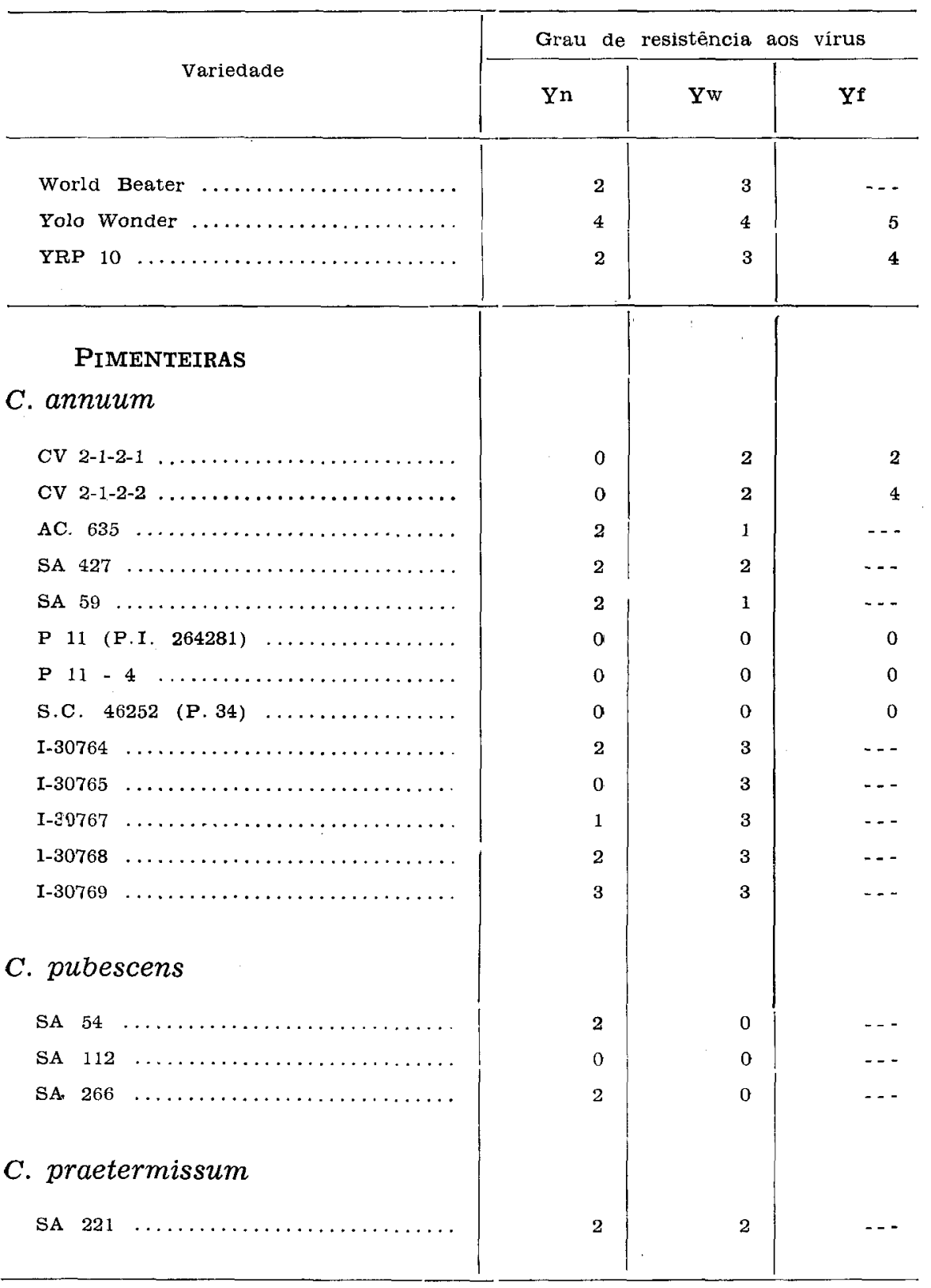


QUAdRo 1. - (Continuação)

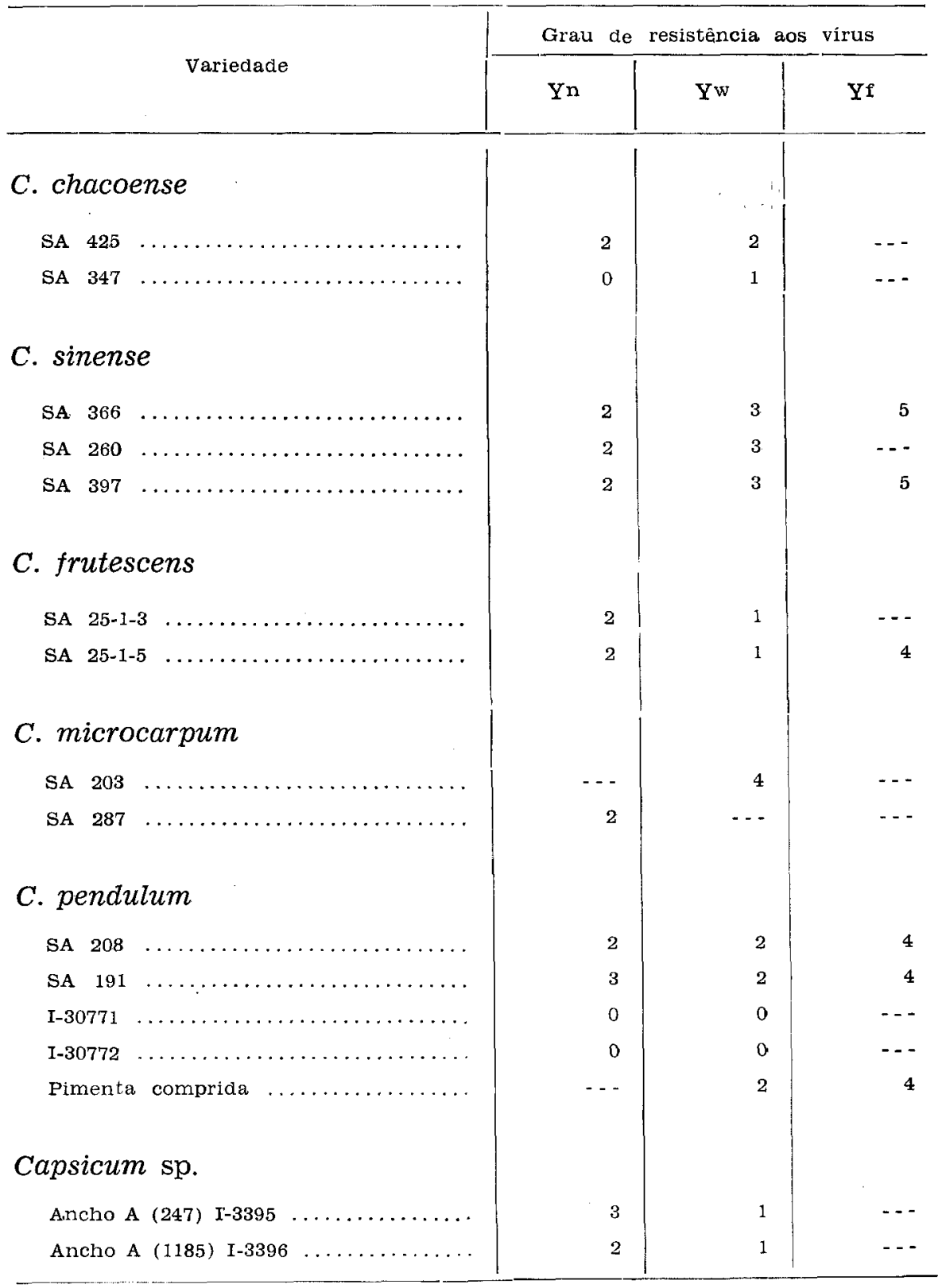


QUADro 1. - (Continuação)

\begin{tabular}{|c|c|c|c|}
\hline \multirow{2}{*}{ Variedade } & \multicolumn{3}{|c|}{ Grau de resistência aos virus } \\
\hline & $\mathrm{Yn}^{\mathrm{n}}$ & $\mathrm{Yw}$ & Yf \\
\hline Ancho A (1225) I-3309 . & 3 & 1 & $\ldots$ \\
\hline Ancho A (1256) I-3401 .. & 2 & 1 & - \\
\hline Ancho A (1297) I-3400 $\ldots$ & 3 & 2 & $-\cdots$ \\
\hline Cotaxtla I-3266 $\ldots \ldots \ldots$ & 0 & 1 & 2 \\
\hline Comari I-3227 ... & 3 & 3 & $\cdots$ \\
\hline Comum I-1 158 & 0 & 1 & 3 \\
\hline Chifre-de-veado I- 2757 & 1 & 2 & 4 \\
\hline Malagueta I-2723 $\ldots \ldots$ & 0 & -- & -- \\
\hline Mulato $M$ (1908) I-3397 ...... & 2 & 2 & 3 \\
\hline Passilla P (9004) I-3398 $\ldots \ldots \ldots$ & 3 & 1 & 3 \\
\hline $\mathrm{I}-30773 \ldots \ldots \ldots \ldots \ldots$ & 2 & 3 & $\ldots$ \\
\hline $\mathrm{I}-30774 \ldots \ldots \ldots \ldots$ & 2 & 3 & -- \\
\hline
\end{tabular}

E. Reação ao virus $Y^{w}$ - A variedade Pôrto Rico Wonder inoculada com a estirpe $\mathrm{w}$ do vírus $\mathrm{Y}$ apresentou leve mosaico nas fôlhas. O vírus não reduz aparentemente o crescimento da planta, e esta produz frutos normalmente. Introduções mais recentes, como Moura, Chifre-de-boi, Ikeda (Ide) etc., pràticamente não mostram sintomas visiveis.

C. Reação ao vírus $\mathrm{Y}^{\mathrm{f}}$ - $\mathrm{O}$ mesmo tipo de reação anteriormente clescrito foi observado em relação ao vírus $\mathrm{Y}^{\mathrm{f}}$, nas variedades Moura, Avelar, Chifre-de-boi e Ikeda (Ide), quando inoculadas mecânicamente. Estas variedades apresentaram ligeiro mosqueamento que se desenvolve lentamente. O vírus pode ser recuperado dessas plantas.

Nenhuma destas estirpes do vírus $\mathrm{Y}$, inoculadas na var. $\mathrm{P} 11$, induziu sintomas de mosaico, até mesmo depois de podada a planta e deixada para observação durante um ano. Tentativas de recuperação do vírus inoculado, nāo só da própria var. P 11, mas também das progênies derivadas que incorporaram o fator responsável, tanto das fôlhas inoculadas como das fôlhas novas, 
sempre foram negativas. Êste fato sugere que o vírus não está presente nos segregantes que não mostram sintomas, e que esta reação poderia ser imunidade.

\subsection{3 - HERANÇA DOS FATÔRES DE RESISTÊNCIA}

Através de cruzamentos e retrocruzamentos entre variedades resistentes e suscetíveis, foram analisados os fatôres genéticos envolvidos na resistência.

\subsubsection{1 - RESISTÊNCIA AO VIRUS $\mathrm{Y}^{\mathrm{n}}$}

Os resultados da inoculação com a estirpe $\mathrm{n}$ do vírus $\mathrm{Y}$ nas progênies $F_{1}$ e $F_{2}$ dos cruzamentos entre variedades Casca Dura, Mogi das Cruzes, Pôrto Rico Wonder e Yolo Wonder em tôdas as combinaçōes estāo apresentados nos quadros 2 e 3 . Os quaàros mostram que tôdas as progênies em que Casca Dura ou Mogi das Cruzes ou ambas conjuntamente fizeram parte no cruzamento apresentaram resistência ao vírus $\mathrm{Y}^{\mathrm{n}}$. Êsses resultados indicam, através do teste de $\mathrm{X}^{2}$, que é aceitável a hipótese de que alelos simples e dominantes condicionam a resistência ao vírus $\mathrm{Y}^{\mathrm{n}}$ nas variedades Casca Dura e Mogi das Cruzes. Os quadros 4 e 5 apresentam analiticamente a segregação dos alelos encontrados nessas duas variedades, respectivamente, quando cruzadas com variedades suscetíveis e resistentes. Os resultados obtidos nos testes de inoculação relativos às plantas retrocruzadas para ambos os pais estão restritos sòmente às progênies derivadas dessas duas variedades. As demais combinações, nas quais nem Casca Dura nem Mogi das Cruzes tomaram parte no cruzamento, foram suscetiveis ao vírus. Por ser desnecessário para a finalidade do trabalho, não estão apresentadas integralmente.

Pequena discrepância nos resultados, como por exemplo, $(\mathrm{PR} \times \mathrm{YW}) \mathrm{F}_{2}$ e seu recíproco $(\mathrm{YW} \times \mathrm{PR}) \mathrm{F}_{2}$, no quadro 3 , onde surgem plantas não infetadas, deveria ser explicada como decorrência de erros experimentais inevitáveis no trabalho, atribuídos à mistura de sementes ou de mudas, polinização natural com o pólen da planta resistente ou a falha de inoculação, e não deveria ser considerada como resistência.

Os estudos efetuados sôbre a herança da reação hipersensivel indicam que tal comportamento das variedades Casca Dura e Mogi das Cruzes estaria condicionado por um par de alelos dominantes, idênticos nas duas variedades. Este fator genético recebeu a designação de " $\mathrm{H}$ ". 
QUADRo 2. - Número de plantas com e sem resistência ao vírus Yn no $\mathrm{F}_{1}$ dos cruzamentos entre quatro variedades de pimentão, em tôdas as combinações

\begin{tabular}{|c|c|c|c|}
\hline \multirow[b]{2}{*}{ Cruzamento $\left({ }^{1}\right)$} & \multicolumn{3}{|c|}{ Número de plantas } \\
\hline & Total inoculado & Resistentes & Suscetíveis \\
\hline $\mathrm{CD} \times \mathrm{MC} \ldots \ldots \ldots$ & 158 & 158 & 0 \\
\hline $\mathrm{CD} \times \mathrm{PR} \ldots \ldots \ldots \ldots$ & 107 & 107 & 0 \\
\hline $\mathrm{CD} \times \mathrm{YW} \ldots \ldots \ldots$ & 89. & 88 & 1 \\
\hline $\mathrm{MC} \times \mathrm{CD} \ldots \ldots \ldots \ldots$ & 77 & 77 & 0 \\
\hline $\mathrm{MC} \times \mathrm{PR} \ldots \ldots \ldots$ & 92 & 92 & 0 \\
\hline $\mathrm{MC} \times \mathrm{YW} \quad \ldots \ldots \ldots$ & 104 & 104 & 0 \\
\hline$P R \times C D \ldots \ldots \ldots \ldots$ & 111 & 108 & 3 \\
\hline $\mathrm{PR} \times \mathrm{MC} \ldots \ldots \ldots$ & 75 & 75 & 0 \\
\hline$P R \times Y W \ldots \ldots \ldots$ & 118 & 1 & 117 \\
\hline $\mathrm{YW} \times \mathrm{CD} \ldots \ldots \ldots$ & 77 & 75 & 2 \\
\hline $\mathbf{Y W} \times \mathbf{M C} \ldots \ldots \ldots$ & 41 & 41 & 0 \\
\hline $\mathrm{YW} \times \mathrm{PR} \ldots \ldots \ldots \ldots$ & 125 & 2 & 123 \\
\hline
\end{tabular}

( $\left.{ }^{1}\right)$ CD = Casca Dura (Casca Grossa); $\mathbf{M C}=$ Mogi das Cruzes; $\quad$ PR = Pôrto Rico Wonder; $\mathrm{YW}=$ Yolo Wonder.

QUADRo 3. - Número de plantas com e sem resistência ao vírus Yn nas progênies $F_{2}$ dos cruzamentos entre quatro variedades de pimentão, em tôdas as combinações

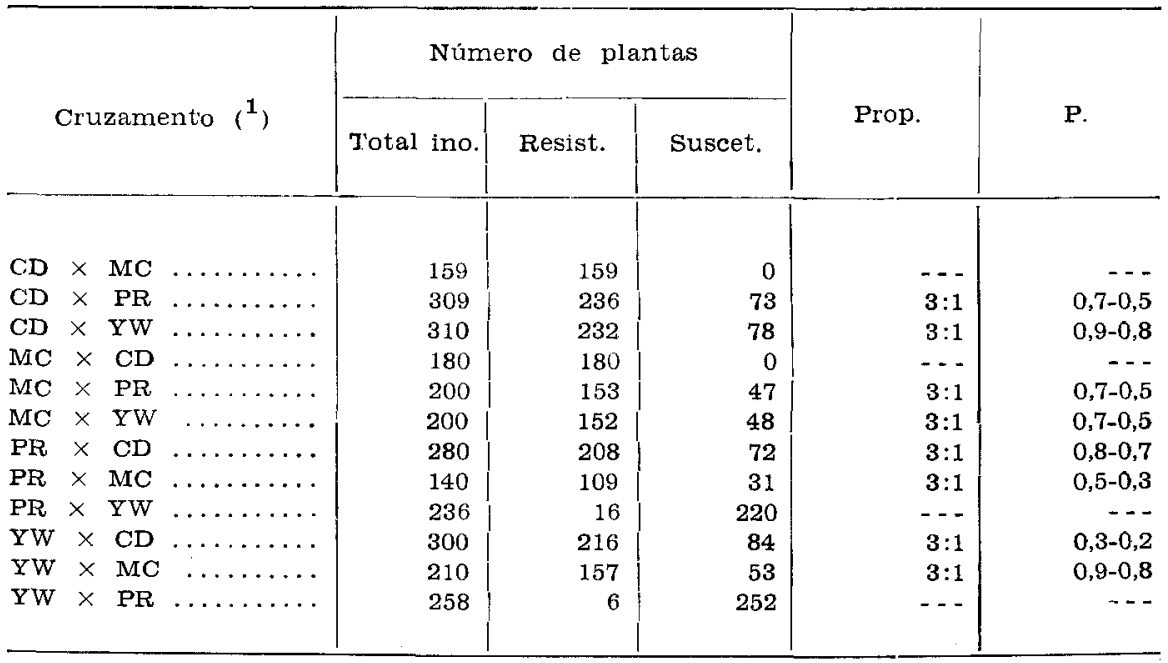

$\mathrm{YW} \stackrel{\left({ }^{1}\right)}{\mathrm{CD}}=$ Casca Dura; $\mathrm{MC}=$ Mogi das Cruzes; $\mathrm{PR}=$ Pôrto Rico Wonder; $\mathrm{YW}=$ Yolo Wonder: Prop. = Proporção observada; $\mathrm{P}$. = Probabilidade. 
Quadro 4. - Resultados analíticos dos cruzamentos sôbre a herança de resistência da variedade CASCA DURA ao vírus $\mathrm{Yn}$, nas gerações $F_{1}, F_{2}$ e retrocruzamentos para ambas as variedades progenitoras

\begin{tabular}{|c|c|c|c|c|c|}
\hline \multirow{2}{*}{$\begin{array}{l}\text { Cruzamento e }\left(^{1}\right) \\
\text { autofecundação }\end{array}$} & \multicolumn{3}{|c|}{ Número de plantas } & \multirow{2}{*}{ Prop. } & \multirow{2}{*}{$P$} \\
\hline & Total ino. & Resist. & suscet. & & \\
\hline $\mathrm{CD} \times \mathrm{MC}$ & & & & & \\
\hline$\ldots \ldots$ & 235 & 235 & 0 & $\cdots$ & $\cdots$ \\
\hline$C(x \quad C D) \ldots$ & 220 & 220 & 0 & $-\cdot$ & -- \\
\hline $\mathrm{C}(\mathrm{x}$ MC) $\ldots \ldots \ldots$ & 240 & 240 & 0 & -- & $\cdots$ \\
\hline$\ldots \ldots \ldots \ldots$ & 339 & 339 & 0 & -- & -- \\
\hline $\mathrm{CD} \times \mathrm{PR}$ & & & & & \\
\hline$\cdots \cdots$ & 218 & 215 & 3 & - . & $-\cdots$ \\
\hline$C\left(\begin{array}{ll}x & C D\end{array}\right)$ & 140 & 140 & 0 & -- & $\cdots$ \\
\hline $\mathrm{C}(\mathrm{x}$ PR $) \ldots \ldots \ldots$ & 144 & 70 & 74 & $1: 1$ & $0,8-0,7$ \\
\hline${ }_{2} \quad \cdots \cdots \cdots \cdots \cdots \cdots$ & 580 & 444 & 145 & $3: 1$ & $0,9-0,8$ \\
\hline $\mathrm{CD} \times \mathrm{YW}$ & & & & & \\
\hline$\cdots \cdots$ & 160 & 166 & 3 & $\cdots$ & $-\cdots$ \\
\hline$C(x \quad C D) \quad \ldots \ldots \ldots$ & 237 & 236 & 1 & $\cdots$ & --- \\
\hline $\mathrm{C}(\mathrm{X} \quad \mathrm{YW}) \ldots \ldots \ldots$ & 217 & 109 & 108 & $1: 1$ & $0,9-0,8$ \\
\hline , $\cdots \cdots \ldots \ldots$ & 610 & 448 & 162 & $3: 1$ & $0,5-0,3$ \\
\hline
\end{tabular}

(1) $\mathrm{CD}=$ Casca Dura; $\mathrm{MC}=$ Mog1 das Cruzes; $\mathrm{PR}=$ Pôrto Rico Wonder; $\mathrm{YW}=$ Yolo Wonder; Prop. $=$ Proporção observada; $\bar{P}$. = Probabilidade; $\mathrm{BC}=$ Retrocruzamento. 
QUADRo 5. - Resultados analíticos dos cruzamentos sôbre a herança de resistência da variedade MOGI DAS CRUZES ao vírus $\mathrm{Yn}$, nas gerações $F_{1}, F_{2}$ e retrocruzamentos para ambas as variedades progenitoras

\begin{tabular}{|c|c|c|c|c|c|}
\hline \multirow{2}{*}{$\begin{array}{l}\text { Cruzamento e }\left({ }^{1}\right) \\
\text { autofecundação }\end{array}$} & \multicolumn{3}{|c|}{ Número de plantas } & \multirow{2}{*}{ Prop. } & \multirow{2}{*}{ P. } \\
\hline & Total ino. & Resist. & Suscet. & & \\
\hline $\mathrm{MC} \times \mathrm{CD}$ & & & & & \\
\hline $\mathrm{F}_{1} \ldots \ldots \ldots \ldots$ & 235 & 235 & 0 & $\cdots$ & $\cdots$ \\
\hline$B C(x, M C) \ldots$ & 240 & 240 & 0 & $\cdots$ & $\cdots$ \\
\hline $\mathrm{BC} \quad\left(\begin{array}{ll}\mathrm{x} & \mathrm{CD}\end{array}\right)$ & 220 & 220 & 0 & -- & $\cdots$ \\
\hline$F_{2} \ldots \ldots$ & 339 & 339 & 0 & -- & $\cdots$ \\
\hline $\mathrm{MC} \times \mathrm{PR}$ & & & & & \\
\hline $\mathbf{F}_{1} \ldots \ldots$ & 167 & 167 & 0 & -- & $\cdots$ \\
\hline$B C\left(\begin{array}{lll}x & M C\end{array}\right)$ & 190 & 189 & 1 & -- & $\cdots$ \\
\hline $\mathrm{BC}(\mathrm{x} \quad \mathrm{PR}) \ldots \ldots$ & 229 & 125 & 104 & $1: 1$ & $0,2-0,1$ \\
\hline$F_{q}$ & 340 & 262 & 78 & $3: 1$ & $0,5-0,3$ \\
\hline $\mathrm{MC} \times \mathrm{YW}$ & & & & & \\
\hline $\mathbf{F}_{1}$ & 145 & 145 & 0 & -- & $\ldots$ \\
\hline $\mathrm{BC}(\mathrm{x} \quad \mathrm{MC})$ & 120 & 120 & 0 & $\cdots$ & - \\
\hline$B C(x \quad Y W)$ & 287 & 127 & 110 & $1: 1$ & $0,3-0,2$ \\
\hline $\mathbf{F}_{q_{2}} \cdots$ & 410 & 309 & 101 & $3: 1$ & $0,9-0,8$ \\
\hline
\end{tabular}

(1) $\mathrm{MC}=$ Mogi das Cruzes: $\mathrm{CD}=$ Casca Dura; $\mathbf{P R}=$ Pôrto Rico Wonder; $\mathrm{YW}=$ Yolo Wonder; Prop. = Proporção observada; $\overline{\mathbf{P}}$ = Probabilidade; $\mathbf{B C}=$ Retrocruzamento. 
3.1.3.2 - RESISTENCIA AO VIRUS $\mathrm{Y}^{\mathrm{W}}$

Número de progênies $F_{1}$ e $F_{2}$ resistentes e suscetiveis ao virus $\mathrm{Yw}^{\mathrm{w}}$, derivadas dos cruzamentos entre a variedade resistente Pôrto Rico Wonder e as variedades suscetíveis Casca Dura, Mogi das Cruzes e Yolo Wonder, em tôdas as combinações possíveis, figura nos quadros 6 e 7 .

Em vista dos resultados obtidos e analisados por teste de $\mathrm{X}^{2}$, verifica-se que a resistência da var. Pôrto Rico Wonder ao virus $\mathrm{Y}^{\mathrm{w}}$ seria controlada por um par de genes recessivos. Testes de retrocruzamento confirmam os mesmos resultados (quadro 8 ). Éste fator genético responsável pela resistência ao vírus $\mathrm{Y}^{\mathrm{w}}$ recebeu a designação de "w".

A var. Moura também se mostrou resistente ao vírus $\mathrm{Y}^{\mathrm{w}}$. As progênies derivadas do cruzamento com a var. Pôrto Rico Wonder não segregaram significativamente (quadro 8). Êste fato indica que ambas as variedades possuem alelos idênticos, responsáveis pela resistência ao vírus $\mathbf{Y}^{\mathrm{w}}$.

\subsubsection{3 - RESISTENCIA AO VIRUS $\frac{f}{\mathbf{Y}}$}

Os resultados obtidos nos testes de inoculação e apresentados em forma analítica constam do quadro 9. Neste quadro, a variedade Moura demonstra possuir um par de genes recessivos, os quais seriam alelos do fator de resistência da var. Pôrto Rico Wonder, mas conferindo o nível de resistência mais elevado. $\mathrm{O}$ fator responsável pela resistência ao vírus $\mathrm{Y}^{\mathrm{f}}$, encontrado na var. Moura, foi designado com o simbolo " $f$ ".

Uma vez que o nível de resistência ao vírus $\mathrm{Y}^{\mathrm{f}}$ apresentado pela var. Pôrto Rico Wonder era relativamente elevado, as progênies $\mathbf{F}_{2}$ do cruzamento entre Moura e Pôrto Rico Wonder mostraram segregação de difícil classificação, pois a diferença entre com e sem fator " $f$ " era pequena nestas progênies. Além disso, não houve segregantes para o nível de suscetibilidade igualável ao das variedades Casca Dura e Yolo Wonder. Assim, há indicação de alelismo entre Moura e Pôrto Rico Wonder, o que, aliás, foi observado no comportamento destas variedades em relação ao vírus $\mathrm{Y}^{\mathrm{w}}$.

Por outro lado, o comportamento da var. $P 11$ em relação ao virus $\mathrm{Y}^{f}$ permitiu diferenciar a imunidade desta do alto nivel de resistência da var. Moura. Assim é que os resultados dos testes 
QUadro 6. - Número de plantas com e sem resistência ao vírus $\mathrm{Y}^{\mathrm{w}}$ no $F_{1}$ dos cruzamentos entre quatro variedades de pimentão, em tôdas as combinações

\begin{tabular}{|c|c|c|c|}
\hline \multirow{2}{*}{ Cruzamento $\left({ }^{1}\right)$} & \multicolumn{3}{|c|}{ Número de plantas } \\
\hline & Total inoculado & Resistentes & Suscetíveis \\
\hline $\mathrm{CD} \times \mathrm{MC} \ldots \ldots \ldots$ & 15 & 0 & 15 \\
\hline $\mathrm{CD} \times \mathrm{PR} \ldots \ldots \ldots \ldots$ & 20 & 0 & 20 \\
\hline$C D \times Y W \ldots \ldots \ldots$ & 15 & 0 & 15 \\
\hline $\mathrm{MC} \times \mathrm{CD} \ldots \ldots \ldots \ldots$ & 15 & 0 & 15 \\
\hline $\mathrm{MC} \times \mathrm{PR} \ldots \ldots \ldots \ldots$ & 15 & 0 & 15 \\
\hline $\mathrm{MC} \times \mathrm{YW} \ldots \ldots \ldots$ & 15 & 0 & 15 \\
\hline$P R \times C D \ldots \ldots \ldots \cdots$ & 15 & 0 & 15 \\
\hline $\mathrm{PR} \times \mathrm{MC} \ldots \ldots \ldots \ldots$ & 15 & 0 & 15 \\
\hline $\mathrm{PR} \times \mathrm{YW} \ldots \ldots \ldots \ldots$ & 1.5 & 0 & 15 \\
\hline $\mathrm{YW} \times \mathrm{CD} \ldots \ldots \ldots \ldots$ & 15 & 0 & 15 \\
\hline $\mathrm{YW} \times \mathrm{MC} \ldots \ldots \ldots \ldots$ & 15 & 0 & 15 \\
\hline $\mathrm{YW} \times \mathrm{PR} \ldots \ldots \ldots \ldots$ & 80 & 0 & 30 \\
\hline
\end{tabular}

$\left({ }^{1}\right) \mathrm{CD}=$ Casca Dura; $\mathrm{MC}=$ Mogi das Cruzes; $\mathrm{PR}=$ Pôrto Rico Wonder;

$\mathrm{YW}=$ Yolo Wonder.

QUADRo 7. - Número de plantas com e sem resistência ao vírus $Y w$ nas progênies $F_{2}$ dos cruzamentos entre quatro variedades de pimentão, em tôdas as combinações

\begin{tabular}{l}
\hline \\
\hline
\end{tabular}


QUADRo 8. - Resultados analíticos dos cruzamentos sôbre a herança de resistência da variedade PÓRTO RICO WONDER ao vírus $Y \mathrm{w}$, nas gerações $F_{1}, F_{2}$ e retrocruzamentos para ambas as variedades progenitoras

\begin{tabular}{|c|c|c|c|c|c|}
\hline \multirow{2}{*}{$\begin{array}{l}\text { Cruzamento e } \\
\text { autofecundação }\end{array}$} & \multicolumn{3}{|c|}{ Número de plantas } & \multirow{2}{*}{ Prop. } & \multirow{2}{*}{$\mathrm{P}$. } \\
\hline & Total ino. & Resist. & Suscet. & & \\
\hline $\mathrm{PR} \times \mathrm{CD}$ & & & & & \\
\hline $\mathbf{F}_{1} \ldots \ldots \ldots \ldots \ldots$ & 35 & 0 & 35 & -- & $-\ldots$ \\
\hline BC $(x$ PR $) \ldots \ldots \ldots$ & 84 & 37 & 47 & $1: 1$ & $0.5-0,3$ \\
\hline $\mathrm{BC}(\mathrm{x} \quad \mathrm{CD}) \ldots \ldots \ldots$ & 60 & 2 & 58 & $-\ldots$ & $-\ldots$ \\
\hline $\mathbf{F}_{2} \quad \cdots \cdots \cdots \cdots \cdots \cdots$ & 202 & 52 & 150 & $1: 3$ & $0.9-0,8$ \\
\hline $\mathrm{PR} \times \mathrm{MC}$ & & & & & \\
\hline $\mathbf{F}_{1} \ldots \ldots \ldots \ldots$ & 25 & 0 & 25 & -- & $-\cdots$ \\
\hline$\frac{1}{B C}(x$ PR $) \ldots$ & 84 & 39 & 45 & $1: 1$ & $0,7-0,5$ \\
\hline $\mathrm{BC}(\mathrm{x} \mathrm{MC}) \ldots \ldots \ldots$ & 59 & 3 & 56 & $-\cdots$ & -- \\
\hline$F_{2} \quad \cdots \cdots \cdots \cdots \cdots \cdots$ & 81 & 21 & 60 & $1: 3$ & $0,9-0,8$ \\
\hline $\mathrm{PR} \times \mathrm{YW}$ & & & & & \\
\hline $\mathbf{F}_{1} \ldots \ldots \ldots \ldots \ldots$ & 45 & 0 & 45 & -- & -- \\
\hline BC $(x$ PR $) \ldots$ & 53 & 22 & 31 & $1: 1$ & $0,3-0,2$ \\
\hline $\mathbf{B C}(\mathbf{x} \mathrm{YW}) \ldots \ldots \ldots$ & 44 & 0 & 44 & $\ldots$ & --- \\
\hline $\mathbf{F}_{2} \quad \ldots \ldots \ldots \ldots$ & 200 & 46 & 156 & $1: 3$ & $0,5-0,3$ \\
\hline $\mathrm{PR} \times \mathrm{M}\left({ }^{1}\right)$ & & & & & \\
\hline $\mathbf{F}_{1} \ldots \ldots \ldots \ldots \ldots \ldots$ & 38 & 38 & 0 & -- & $\cdots$ \\
\hline BC $(x$ PR $) \ldots \ldots \ldots$ & 25 & 25 & 0 & -- & --- \\
\hline $\mathbf{B C}(\mathbf{x} \mathbf{M}) \ldots \ldots \ldots$ & 25 & 25 & 0 & -- & $\cdots$ \\
\hline $\mathbf{F}_{\mathbf{2}} \ldots \ldots \ldots \ldots \ldots \ldots$ & 95 & 92 & 3 & $\cdots$ & $-\cdot$ \\
\hline
\end{tabular}

(1) $\mathbf{M}=$ Moura. 
QuAdRo 9. - Resultados analíticos dos cruzamentos sôbre a herança de resistência da variedade MOURA ao vírus $\mathrm{Yf}$, nas gerações $F_{1}, F_{2}$ e retrocruzamentos para ambas as variedades progenitoras

\begin{tabular}{|c|c|c|c|c|c|}
\hline \multirow{2}{*}{$\begin{array}{l}\text { Cruzamento e }\left(^{1}\right) \\
\text { autofecundação }\end{array}$} & \multicolumn{3}{|c|}{ Número de plantas } & \multirow{2}{*}{ Prop. } & \multirow{2}{*}{$\mathbf{P}$. } \\
\hline & Total ino. & Resist. & Suscet. & & \\
\hline $\mathbf{M} \times \mathbf{C D}$ & & & & & \\
\hline $\mathbf{F}_{1} \ldots \ldots \ldots \ldots \ldots \ldots$ & 25 & 0 & 25 & $\cdots$ & -- \\
\hline $\mathrm{BC}(\mathrm{x} \quad \mathrm{M}) \quad \ldots \ldots \ldots$ & 75 & 34 & 41 & $1: 1$ & $0,5-0,3$ \\
\hline $\mathrm{BC}(\mathrm{x} C D) \ldots \ldots \ldots$ & 80 & 2 & 78 & --- & -- \\
\hline $\mathbf{F}_{2} \ldots \ldots$ & 438 & 104 & 334 & $1: 3$ & $0,7-0,5$ \\
\hline $\mathrm{M} \times \mathrm{PR}$ & & & & & \\
\hline $\mathbf{F}_{1} \ldots \ldots \ldots \ldots \ldots \ldots$ & 50 & 49 & 1 & $\cdots$ & -- \\
\hline $\mathbf{B C}(\mathbf{x} \mathrm{M}) \ldots \ldots \ldots \ldots$ & 64 & 62 & 2 & -- & $-\cdot$ \\
\hline $\mathrm{BC}(\mathrm{x} \quad \mathrm{PR}) \quad \ldots \ldots \ldots$ & 58 & 54 & 4 & $-\cdots$ & -- \\
\hline $\mathbf{F}_{2} \cdots \cdots$ & 350 & 338 & 12 & -- & -- \\
\hline $\mathbf{M} \times \mathbf{Y W}$ & & & & & \\
\hline $\mathbf{F}_{1} \ldots \ldots \ldots \ldots \ldots \ldots$ & 25 & 0 & 25 & $\cdots$ & -- \\
\hline $\mathrm{BC}(\mathrm{x} M) \quad \ldots \ldots \ldots$ & 67 & 35 & 32 & $1: 1$ & $0,8-0,7$ \\
\hline$B C(x \quad Y W) \quad \ldots \ldots \cdots$ & 48 & 0 & 48 & $\cdots$ & -- \\
\hline$F_{2} \ldots \ldots \ldots \ldots \cdots \cdots$ & 79 & 19 & 60 & $1: 3$ & $0,9-0,8$ \\
\hline
\end{tabular}

(1) $\quad \mathbf{M}=$ Moura; $\quad \mathrm{CD}=$ Casca Dura; $\quad \mathrm{PR}=$ Pôrto Rico Wonder; $\quad \mathrm{YW}=$ Yolo Wonder; Prop. = Proporção observada; $P .=$ Probabilidade; $B C=$ Retrocruzamento. 
QUADRo 10. - Resultados analíticos dos cruzamentos sôbre a herança de imunidade da variedade P 11 (P.I. 264281) ao vírus Yf, nas gerações $F_{1}, F_{2}$ e retrocruzamentos para ambas as variedades progenitoras

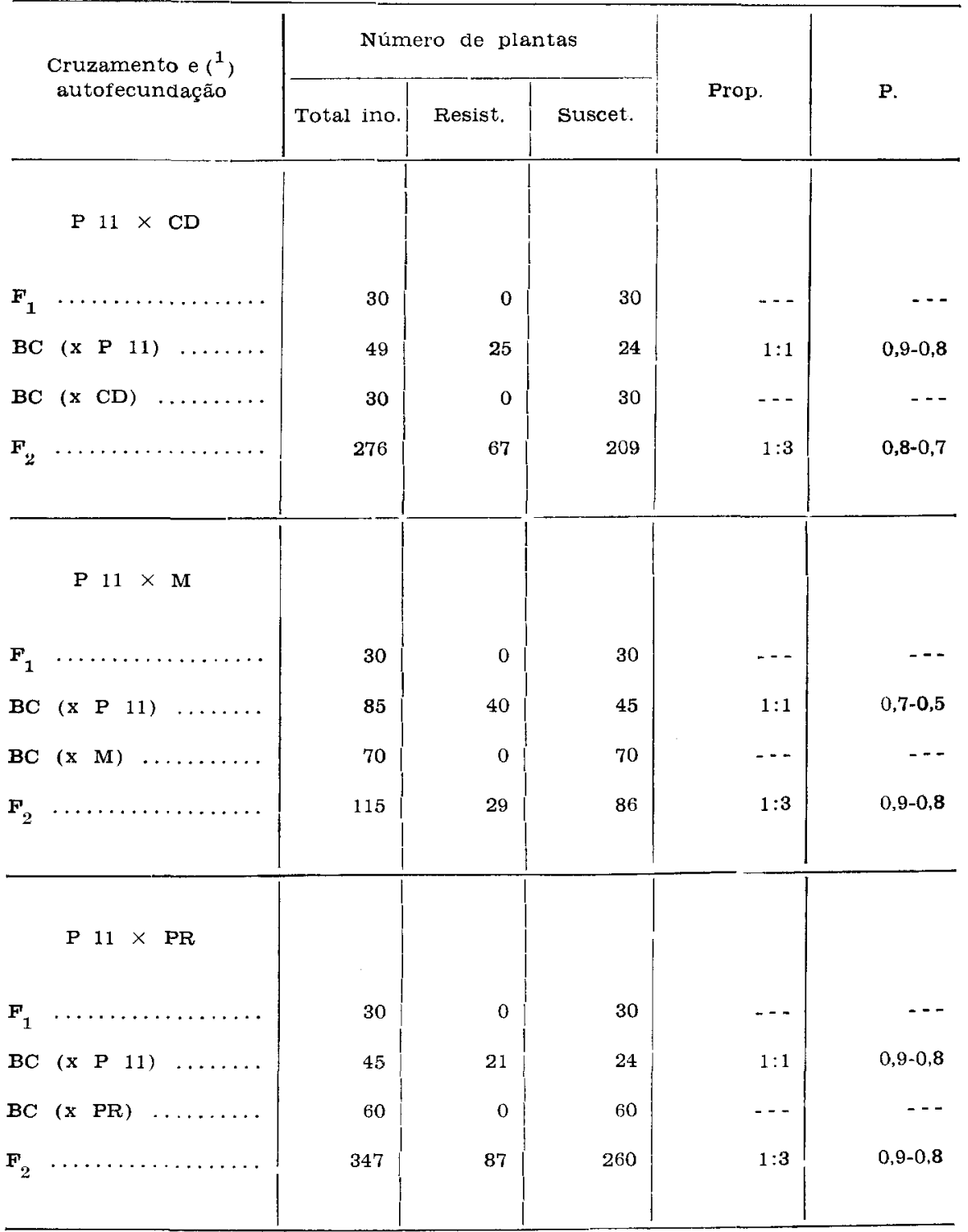

(1) P $11=$ P 11 (P.1. 264281); CD = Casca Dura; $\mathbf{M}=$ Moura; PR = Pôrto Rico Wonder; Prop. = Proporção observada; P. = Probabilidade; $\mathbf{B C}=$ Retrocruzamento 
constantes do quadro 10 mostram segregação de 1 imune para 3 suscetíveis, na população $F^{2}$ dos cruzamentos entre $P 11$ e Moura, entre P 11 e Casca Dura e entre P 11 e Pôrto Rico Wonder. Nestes ensaios, foi possível distinguir plantas imunes das plantas suscetíveis, e das plantas com o nivel da resistência da var. Moura.

Em todos os segregantes, a hipótese de a imunidade ser realmente condicionada por um par de genes recessivos "yaya" (8) encontrou alto nível de probabilidade.

Além dêsses fatôres genéticos que condicionam resistência e imunidade ao vírus $\mathrm{Y}$, foi estudada a resistência (hipersensibilidade) ao vírus de mosaico comum do fumo, a qual é condicionada por genes " $L^{i} L^{\mathrm{i}}$ " $(6,16,17,20)$. As variedades comerciais Yolo Wonder e All Big serviram como fontes de resistência.

Em vista dos resultados obtidos, ficou demonstrado que as variedades escolhidas como fontes de resistência possuem os seguintes genótipos, no que diz respeito a resistência às moléstias de vírus:

CASCA DURA e MOGI DAS CRUZES: Suscetiveis ao TMV (11), hipersensíveis ao vírus $\mathrm{Y}^{\mathrm{n}}(\mathrm{HH})$ e suscetíveis ao vírus $\mathrm{Y}^{\mathrm{w}}(\mathrm{WW})$. "llHHWW"

PÔRTO RICO WONDER: Suscetível ao TMV (11), suscetível ao vírus $\mathrm{Y}^{\mathrm{n}}(\mathrm{hh})$ e resistente ao vírus $\mathrm{Y}^{\mathrm{w}}(\mathrm{ww})$.

YOLO WONDER e ALL BIG: Hipersensíveis ao TMV ( $\left.L^{i} L^{i}\right)$, suscetiveis ao virus $\mathrm{Y}^{\mathrm{n}}(\mathrm{hh})$ e suscetíveis ao virus $\mathrm{Y}^{\mathrm{w}}$ (WW). "LiLihhWW"

MOURA: Resistente ao vírus $\mathrm{Y}^{\mathrm{f}}$ (ff) e suscetível ao vírus $\mathrm{Y}^{\mathrm{n}}(\mathrm{hh})$. ....... "ffhh"

P 11 (P.I. 264281): Imune às estirpes testadas do vírus Y. ....... "yalya"

3.2 - INCORPORAÇĀO DOS FATÔRES DE RESISTENNCIA, SELEÇÃO DE LINHAGENS RESISTENTES E SUAS CARACTERÍSTICAS

Neste capítulo são descritos os processos pelos quais os fatôres de resistência foram incorporados e combinados, a fim de obter híbridos resistentes ao mosaico. Como, por vêzes, os tra- 
balhos tiveram a sua diretriz alterada, em decorrência dos resultados anteriormente obtidos e do surto da estirpe mais severa, incluímos sucinto comentário em tôrno do andamento do trabalho nessas circunstâncias.

Para a melhor compreensão do processo adotado, o desenvolvimento das linhagens que deram origem às novas variedades Agronômico 7 e Agronômico 8 é historiado em sequiência natural. As relaçōes em derivação das linhagens estão esquematizadas na figura 1, na qual a numeração indica as etapas do trabalho, e a sua posição, a época da operação.

Etapa 1 - Testes iniciais de resistência das variedades comerciais - Neste ensaio foram testadas as variedades de pimentão constantes da relação apresentada no item 3.2., excetuando-se aquelas introduzidas posteriormente, como Moura, Chifre-de-boi, Avelar, Ikeda (Ide) etc. Foram inoculadas mecânicamente com as estirpes $n$ e $\mathrm{w}$ do vírus $\mathrm{Y}$, além dos vírus de menor importância, tais como: Vira-cabeça do tomateiro, mosaico do pepino, mosaico do fumo, necrose branca do fumo, amarelo do tomateiro etc. Os resultados obtidos (quadro 1) evidenciaram fontes promissoras de resistência aos vírus $\mathrm{Y}^{\mathrm{n}}$ e $\mathrm{Y}^{\mathrm{w}}$ nas variedades Casca Dura e Mogi das Cruzes para o primeiro, e Pôrto Rico Wonder para o segundo. Resistência ao TMV foi confirmada nas variedades Yolo Wonder e All Big, decidindo-se a sua inclusão no programa de melhoramento.

Um ensaio de campo, realizado em colaboração com a seção de Olericultura, do Instituto Agronômico, comparando sete variedades de pimentão, confirmou o grau mais elevado de resistência ao mosaico, na variedade Pôrto Rico Wonder (dados não publicados ).

Etapa 2 - Cruzamentos entre quatro variedades, em tôdas as combinações - Em virtude de cada uma das fontes de resistência ser suscetivel aos demais vírus, fêz-se necessário combinar as fontes de resistência. As plantas inoculadas no teste anterior serviram para os cruzamentos.

Etapa 3 - Geração $F_{1}$ das progênies dos cruzamentos - As progênies $F_{1}$ dos cruzamentos foram divididas em três grupos, em cada um dos quais foram inoculados os vírus $\mathrm{Y}^{\mathrm{n}}, \mathrm{Y}^{\mathrm{w}}$ e TMV, separadamente.

Os híbridos derivados de Casca Dura e de Mogi das Cruzes não apresentaram nenhum sintoma do vírus $\mathrm{Y}^{\mathrm{n}}$, enquanto as 
plantas derivadas de Yolo Wonder se mostraram hipersensiveis ao TMV. Nenhuma combinação se apresentou resistente ao vírus $\mathrm{Y}^{\mathrm{w}}$ (quadros 2 e 6 ).

Etapa 4 - Geração $F_{2}$ das progênies dos cruzamentos - As proporções observadas nas segregações da população $F_{2}$, conforme os dados apresentados nos quadros 3, 4 e 5, indicaram que a resistência ao vírus $\mathrm{Y}^{\mathrm{n}}$ encontrada nas variedades Casca Dura e Mogi das Cruzes é condicionada por fatôres simples e dominantes. Foi verificado, por outro lado, que a resistência ao vírus $\mathrm{Y}^{\mathrm{w}}$ encontrada na variedade Pôrto Rico Wonder é controlada por um par de genes recessivos (quadros 7 e 8 ).

Os híbridos $F_{2}$ derivados da Pôrto Rico Wonder e resistentes ao vírus $\mathrm{Y}^{\mathrm{w}}$ podem possuir também resistência ao vírus $\mathrm{Y}^{\mathrm{n}}$ ou ao TMV, dependendo de a planta ser descendente de Casca Dura ou Yolo Wonder. Por esta razão, as progênies resistentes ao vírus $\mathrm{Y}^{\mathrm{w}}$ foram em seguida inoculadas com 0 virus $\mathrm{Y}^{\mathrm{n}}$ ou com TMV. Resultaram dai um grupo de plantas resistentes aos vírus $\mathrm{Y}^{\mathrm{w}}$ e $\mathrm{Y}^{\mathrm{n}}$ e um grupo de plantas resistentes aos vírus $\mathrm{Y}^{\mathrm{w}}$ e TMV, representados em 4-A e 4-B, na figura 1, respectivamente.

Etapa 5 - Cruadmentos entre geração $F^{2}$ dos cruzamentos - Cruzaram-se dois grupos de híbridos selecionados, dando origem a progênies resistentes ao vírus $\mathrm{Y}^{\mathrm{w}}$ em homozigose, e combinando os fatôres dominantes de resistência ao TMV e ao vírus $\mathrm{Y}^{\mathrm{n}}$.

Etapa 6 - Seleçāo de plantas resistentes aos três virus Nesta etapa os híbridos duplos foram submetidos às inoculações com os vírus $\mathrm{Y}^{\mathrm{n}}, \mathrm{Y}^{\mathrm{w}}$ e TMV, as quais se processaram em ordem estabelecida de acôrdo com as reações de resistência.

A reação ao vírus $\mathrm{Y}^{\mathrm{n}}$ é hipersensível, mas os efeitos práticos sāo do tipo imunidade. A reação ao TMV é também do tipo hipersensivel, porém acompanhado de abscisão das fôlhas inoculadas, enquanto que a resistência ao vírus $\mathrm{Y}^{\mathrm{w}}$ é averiguada num periodo maior. Conseqüentemente, o vírus $\mathrm{Y}^{\mathrm{n}}$ foi inoculado em primeiro Iugar, seguido, após eliminação das plantas suscetíveis, pela inoculação com o vírus $\mathrm{Y}^{\mathrm{w}}$. TMV foi inoculado mais tarde nas plantas resistentes aos vírus $\mathrm{Y}^{\mathrm{n}}$ e $\mathrm{Y}^{\mathrm{w}}$.

Etapa 7 - Seleção dos hibridos trifatoriais - Ao serem autofecundadas, as plantas resistentes aos três vírus foram selecionadas quanto ao formato e ao tamanho dos frutos, para que o 
produto fôsse similar ao da var. Casca Dura. A seleção das progênies para resistência aos vírus foi efetuada de maneira idêntica à que foi realizada na geração anterior.

Etapa 8 - Seleção e teste de progênies $F_{3}$ dos híbridos trifatoriais - Novamente submetidas à seleção pelo tipo dos frutos, as progênies foram testadas quanto à resistência aos três vírus por meio de inoculações sucessivas.

Etapa 9 - Ensaio de campo do Agronômico 1 - As progênies selecionadas pelos testes de resistência, e homozigotas para os

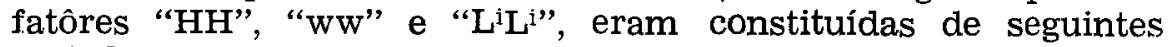
variedades:

$\mathrm{F}_{4} \quad\left[(\right.$ Casca Dura $\times$ P. R. W. $) F_{2} \times($ Yolo Wonder $\times$ P. R. W. $\left.) F_{2}\right]$

Os híbridos selecionados foram denominados Agronômico 1. A designação Agronômico indica grupo de progênies ou linhagens com características comuns.

Esstes híbridos foram experimentados no campo, sob condições naturais de infecção, em comparação com as variedades originais, na Est. Exp. Cent. “Theodureto de Camargo". Desde logo, foi observada a severa infecção do vírus nas variedades Casca Dura e Yolo Wonder, enquanto o Agronômico 1 foi infetado ao nível correspondente ao da var. Pôrto Rico Wonder, e ambas mostraram o grau de severidade bastante elevado. Ao final do ensaio, tanto a var. Pôrto Rico Wonder quanto as progênies hibridas selecionadas estavam mostrando o grau de reação entre 3 e 4 da escala convencional (item 2.3.1 - B).

Os resultados verificados sugeriram que o baixo nivel de resistência observado no ensaio seria conseqüência do surto de uma variante mais severa que o vírus $\mathrm{Y}^{\mathrm{w}}$, o que mais tarde foi confirmado (Etapa 14).

Eıapa 10 - Introdução da var. Moura - Na ocasião da introdução da variedade chamada Moura, que se mostrou tolerante ao vírus $\mathrm{Y}^{\mathrm{w}}$ no teste de resistência, o esquema do trabalho visando criar híbridos trifatoriais resistentes aos vírus $\mathrm{Y}^{\mathrm{n}}, \mathrm{Y}^{\mathrm{w}}$ e TMV havia sido estruturado e já se encontrava em execução em fase adiantada. $\mathrm{O}$ nivel de resistência ao virus $\mathrm{Y}^{\mathrm{w}}$ era pràticamente igual ao da var. Pôrto Rico Wonder, e a qualidade do fruto era inferior. Porém, a variedade em questão apresentava maior rusticidade que as demais variedades, no campo, e também havia 
interêsse em verificar se se combinava a resistência desta com a da var. Pôrto Rico Wonde. Por estas razōes, foi iniciado um projeto paralelo, visando aproveitamento do material para novas hibridações.

Etapa 11 - Cruzamentos entre Moura e Pôrto Rico Wonder - De início, a var. Moura foi cruzada com a var. Pôrto Rico Vionder, para verificação do alelismo entre estas variedades quanto à resistência ao vírus $\mathrm{Y}^{\mathrm{w}}$. Ao mesmo tempo, Moura foi cruzada com os derivados de Pôrto Rico Wonder, que incorporaram resistência ao vírus $\mathrm{Y}^{\mathrm{n}}\left(\mathrm{PR} \times \mathrm{MC}^{\mathrm{M}}\right.$ etc. $)$.

Etapa 12 - Progênies $F_{1}$ do cruzamento - As progênies $F_{1}$ do cruzamento entre Moura e Pôrto Rico Wonder, inoculadas com o vírus $\mathrm{Y}^{\mathrm{w}}$, mostraram-se resistentes (quadro 8).

Etapa 13 - Hibridos de Moura resistentes aos virus $Y^{\mathrm{n}}$ e $Y^{\mathrm{w}}$ -- Os resultados apresentados no quadro 8 indicam o alelismo entre fator de resistência ao virus $\mathrm{Y}^{\mathrm{w}}$ encontrado na var. Moura e o fator de resistência encontrado na var. Pôrto Rico Wonder.

A população $F_{2}$ resultante do cruzamento entre Moura e os derivados de Pôrto Rico Wonder resistentes aos vírus $\mathrm{Y}^{\mathrm{n}}$ e $\mathrm{Y}^{\mathrm{w}}$ foi inoculada com êstes dois vírus. Foram desta maneira selecionadas plantas derivadas de Moura e resistentes aos virus $\mathrm{Y}^{\mathrm{n}}$ e $\mathrm{Y}^{\mathrm{w}}$.

Etapa 14 - Hibridos de Moura resistentes ao vírus $Y^{\mathrm{f}}-$ No ensaio de campo (Etapa 9), onde se observou o baixo nível de resistência ao mosaico na var. Pôrto Rico Wonder e no Agronômico 1 , foi suposta a possibilidade do surto de uma variante mais severa que o vírus $\mathrm{Y}^{\mathrm{w}}$. Realmente, estudos comparativos com base nas reaçōes de plantas-teste comprovaram a presença de uma nova estirpe, ainda que pertencente ao grupo w. Esta estirpe foi designada $Y^{f}$.

Os híbridos derivados de Moura haviam sido selecionados pelo vírus $\mathrm{Y}^{\mathrm{w}}$ até esta geração. Quando êstes híbridos foram inoculados com o vírus $\mathrm{Y}^{\mathrm{f}}$, ficou demonstrado que a var. Moura e seus derivados possuem fatôres de resistência à nova estirpe. A resistência de Moura ao virus $\mathrm{Y}^{\mathrm{f}}$ foi igualmente comprovada no campo.

Etapa 15 - Seleção de linhagens resistentes ao vírus $Y^{\mathrm{f}}$ A partir desta geração, o vírus $\mathrm{Y}^{\mathrm{f}}$ substituiu $\mathrm{O} \mathrm{Y}^{\mathrm{w}}$ nos testes de 
resistência e nos trabalhos de seleção das plantas resistentes ao virus do grupo $\mathrm{w}$, por permitir a seleção de plantas com nivel mais elevado de resistência.

As progênies derivadas de Moura foram selecionadas, visando associar a resistência ao vírus $\mathrm{Y}^{\mathrm{f}} \mathrm{com}$ a melhoria de qualidades econômicas do produto.

$\mathrm{O}$ grupo de progênies resistentes ao vírus $\mathrm{Y}^{f}$ foi denominado Agronômico 2, e era assim constituído (ESTAMPa 2-8):

$\mathrm{F}_{5}$ [Moura $\times$ (Pôrto Rico Wonder $\times$ Mogi das Cruzes) $\mathrm{F}^{2}$ ]

O Agronômico 2 foi experimentado em Campinas, Itapetininga, Indaiatuba, São José dos Campos, Taubaté e Pindamonhangaba, no Estado de São Paulo; Miguel Pereira e Itaguaí, no Estado do Rio; e Santa Cruz, no Estado da Guanabara. Os híbridos demonstraram alto nível de resistência ao mosaico em tôdas essas localidades, em comparação com a var. Casca Dura. Foi observado que os frutos eram menores que os da var. Casca Dura.

Etapa 16 - Cruzamentos entre Agronômico 1 e Agronômico 2 - Como conseqüência dêsses resultados, Agronômico 2 foi cruzado com Agronômico 1, a fim de incorporar resistência ao TMV e ao $\mathrm{Y}^{\mathrm{w}}$, já reunida em Agronômico 1 .

Etapa 17 - Híbrido $F_{1}$ entre Agronômico 1 e Agronômico 2 - Como era sabido que Agronômico 1 e Agronômico 2 possuiam alelos para resistência ao vírus $\mathrm{Y}^{\mathrm{n}}$, e que Agronômico 1 possuia um par de fatôres dominantes para suscetibilidade ao vírus $\mathrm{Y}^{\mathrm{f}}$, os híbridos $F_{1}$ foram autofecundados para obter progênies $F_{2}$.

Etapa 18 - Seleção da população $F_{2}$ dos híbridos entre Agronómico 1 e Agronômico 2 - Por meio de inoculação mecânica com o vírus $\mathrm{Y}^{\mathrm{f}}$, foram obtidas progênies resistentes e homozigotas para os genes "HH" e "ff".

Etapa 19 - Ensaios de Campo - As progênies $F_{3}$ foram plantadas no campo, onde foram selecionadas as melhores plantas. Antes do transplante, as mudas foram inoculadas com o vírus $\mathrm{Y}^{\mathrm{f}}$.

Etapa 20 - Experimentos com Agronômico 3 - O grupo de progênies derivadas de variedades resistentes aos vírus $\mathrm{Y}^{\mathrm{n}}, \mathrm{Y}^{\mathrm{w}}$, $\mathrm{Y}^{\mathfrak{r}}$ e TMV foi denominado Agronômico 3, constituindo-se das seguintes variedades (ESTAMPA 2-9): 
$F_{4}\left\{\left[(\right.\right.$ Casca Dura $\times$ P. R. W. $) F_{:} \times($Yolo W. $\times$P. R. W. $\left.) F_{: 2}\right] F_{4}$ $\times[$ Moura $\times$ P. R. W. $\times$ Mogi das Cruzes $\left.\left.) F_{2}\right] F_{3}\right\}$

O Agronômico 3 foi experimentado em Campinas, Indaiatuba, Pedra Branca e outras localidades, demonstrando elevado nível de resistência a mosaico em tôdas as localidades.

Etapa 21 - Introdução da pimenteira P 11 (P. I. 264281) Foi introduzida da Florida, E.U.A., uma pimenteira chamada $P$ 11. Esta variedade é pertencente à mesma espécie que o pimentão comercial, e possui virtual imunidade ao vírus $\mathrm{Y}$, caráter êste controlado por um par de genes recessivos "yaya" $(2,3,4$, $5,7,8$ ).

No teste de resistência efetuado com as estirpes dos grupos $\mathrm{n}$ e $\mathrm{w}$ do vírus $\mathrm{Y}$, que aqui ocorrem, a variedade $\mathrm{P} 11$ provou ser igualmente imune a essas estirpes. Estudo sôbre a herança da resistência, feito em relaçāo ao vírus $\mathrm{Y}^{\mathrm{f}}$, confirmou o caráter monofatorial recessivo do gene responsável (quadro 10).

Etapa 22 - Hibridaçâo entre $P 11$ e variedades de pimentão - P 11 ( P.I. 264281) foi cruzada com as variedades de pimentão Pôrto Rico Wonder, Casca Dura, Mogi das Cruzes e Yolo Wonder. Não foi constatada nenhuma dificuldade relacionada à incompatibilidade na hibridação.

Etapa 23 - Retrocruzamentos para o pimentão comercial As progênies $F_{1}$ dos híbridos derivados de $P 11$ produziram frutos miúdos e ardidos. Inoculadas com o vírus $\mathrm{Y}^{\mathrm{w}}$, mostraram-se suscetíveis. Como era conhecida a herança da resistência ao mosaico e dos fatôres genéticos que envolvem a presença do ardume, uma parte das progênies foi autofecundada e outra foi retrocruzada com respectivas variedades de pimentão.

Etapa 24 - Seleção pelo tipo e tamanho dos frutos - Na geração $F_{1}$ do retrocruzamento para o pimentão, foram selecionadas progênies que apresentavam melhor tipo e tamanho dos frutos, enquanto as progênies $F_{2}$ do cruzamento foram descartadas por não apresentarem progênies promissoras para o objetivo desejado.

Etapa 25 - Seleção das plantas com as características melhores - Grande número da população $F_{2}$ do retrocruzamento foi inoculado com o vírus $\mathrm{Y}^{\mathrm{w}}$, na fase inicial da cultura, e depois, 
transplantado no campo. Foram observadas segregaçōes quanto à resistência ao vírus, tamanho e formato dos frutos e presença do ardume. Nesta população, foi possivel selecionar indivíduos resistentes ao mosaico, produzindo frutos doces e de tipo comercial.

Etapa 26 - Seleção dos híbridos $F_{3}(B C)$ - Procedeu-se novamente a seleção individual nas progênies $F_{3}$ do retrocruzamento. Nesta geração as progênies derivadas da var. Pôrto Rico Wonder foram descartadas por não mostrarem melhoria dos frutos (EsTAMPA 2-7). As demais progênies demonstraram possibilidade favorável à obtenção de frutos doces e de tipo comercial, entre plantas que incorporaram o fator de imunidade.

Etapa 27 - Seleção dos hibridos $F_{4}(B C)$ - Vários grupos de progênies derivadas de $\mathrm{P} 11$ mostraram-se imunes ao virus $\mathrm{Y}^{f}$ e apresentaram frutos do tipo de pais recorrentes.

Etapa 28 - Agronômico 4, Agronômico 5 e Agronômico 6 As progênies derivadas dos cruzamentos entre $P 11$ e três variedades de pimentão constituiram três tipos de Agronômico, imunes ao vírus $\mathrm{Y}^{\mathrm{f}}$.

Agronômico 4: Produziu frutos bastante alongados (EsTAMPa 2-10).

$F_{\bar{i}} \quad\left[(\right.$ Casca Dura $\times P 11) F_{1} \times$ Casca Dura $]$

Agronômico 5: Apresentou frutos do tipo quadrado.

$F_{5} \quad$ (Yolo Wonder $\left.\times P 11\right) F_{1} \times$ Yolo Wonder $\left.)\right]$

Agronômico 6: Mostrou formato característico da variedade recorrente.

$F_{5} \quad\left[\left(\text { Mogi das Cruzes } \times \mathrm{P}_{11}\right)_{1} \times\right.$ Mogi das Cruzes]

Etapa 29 - Cruzamentos entre Agronômico 3 e derivados de $P 11$ - As progênies selecionadas de Agronômico 4 foram autofecundadas para fixar o formato apresentado, ao passo que Agronômico 5 e Agronômico 6 foram cruzados com Agronômico 3 com a finalidade de incorporar numa planta maior número possível de genes de resistência às moléstias de vírus.

Etapa 30 - Geração autofecundada - Sendo conhecidos os genótipos de Agronômico 3 e dos derivados de $P$ 11, os híbridos obtidos foram autofecundados na casa de vegetação. 
Etapa 31 - Seleção de pimentão imune ao mosaico - As progênies $F_{2}$ foram inoculadas com o virus $\mathrm{Y}^{\mathrm{q}}$. As plantas homozigotas para os genes "yay" mostraram-se imunes ao mosaico, enquanto as demais mostravam tolerância ao vírus.

Os derivados de Agronômico 5 apresentaram tendência para produzir frutos quadrados, ao passo que os derivados de Agronômico 6 foram selecionados para produzir frutos cônicos, semelhantes aos da var. Casca Dura.

Etapa 32 - Seleção pelas qualidades comerciais - Uma vez fixada a resistência de alto nível ao mosaico nas progênies derivadas de variedades P 11, Moura, Pôrto Rico Wonder, Yolo Wonder e Casca Dura, as progênies obtidas foram submetidas a seleção pela qualidade comercial do fruto.

Etapa 33 - Seleção final de Agronômico 7 e Agronômico 8 - Desta maneira foram obtidas duas linhagens de pimentão imunes ao mosaico e que produzem dois padrōes comerciais de frutos, quadrado e cônico, respectivamente denominadas Agronômico 7 e Agronômico 8.

Agronômico 7: Frutos do tipo California Wonder (estaMpa 2-11). $F_{4}$ (Agronômico 3 x Agronômico 5)

Agronômico 8: Frutos do tipo Casca Dura (estampa 2-12).

$\mathrm{F}_{4}$ (Agronômico $3 \times$ Agronômico 6)

Como qualidade adicional, muitas das linhagens, tanto do Agronômico 7 como do Agronômico 8, possuem resistência ao vírus do mosaico comum do fumo, embora não seja possível saber se o fator de resistência derivou do Agronômico 3 ou da var. $P 11$.

Pelos conhecimentos adquiridos nos levantamentos de viroses e pelos dados obtidos nos ensaios anteriores, espera-se o comportamento satisfatório dessas duas linhagens resistentes dentro do Estado de São Paulo e nos Estados vizinhos.

\section{4 - DISCUSSÃO}

4.1 - RESISTÉNCIA DO PIMENTÃo AO GRUPO N DO VIRUS Y

Os resultados obtidos evidenciaram que as variedades Casca Dura e Mogi das Cruzes possuem um par de alelos dominantes, que condicionam hipersensibilidade ao vírus $\mathrm{Y}^{\mathrm{n}}$. Esta reação é 


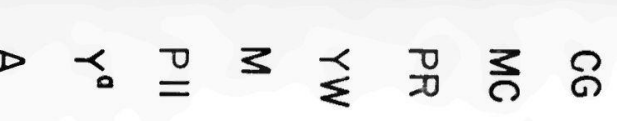

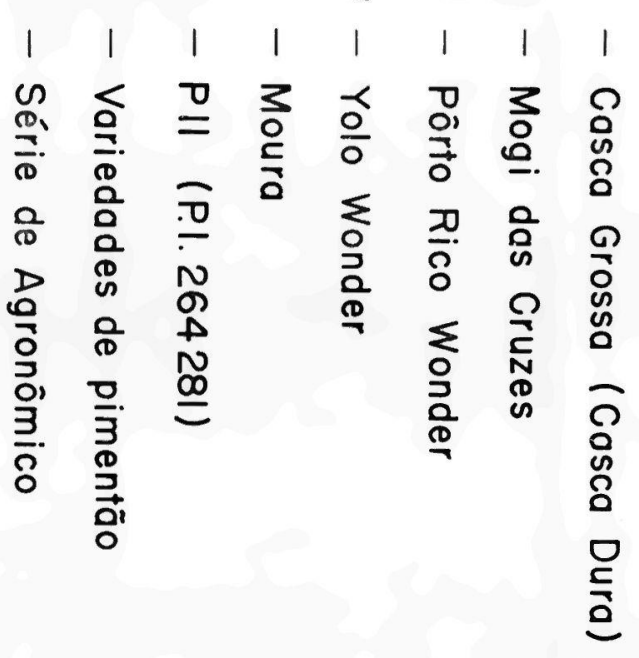

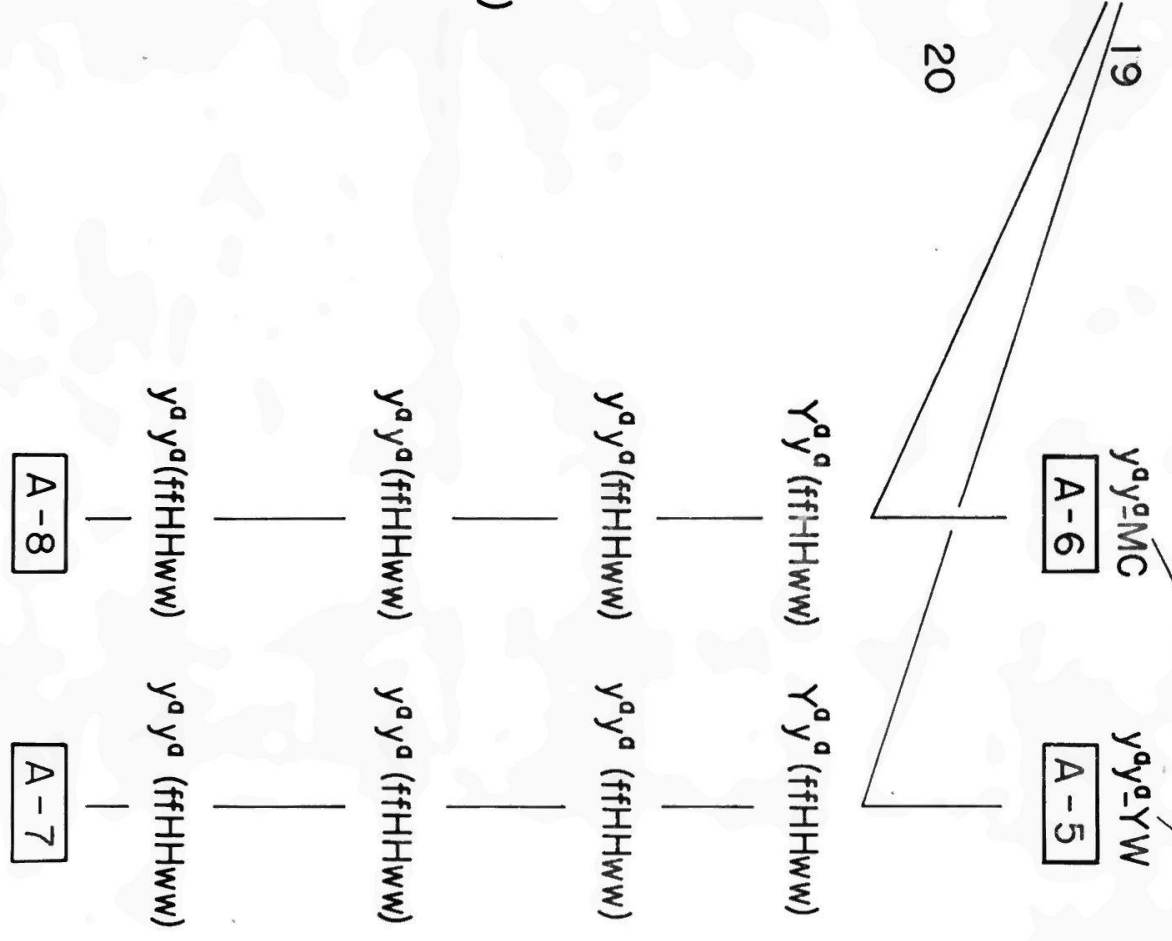

路点

$$
\begin{aligned}
& D \\
& 0 \\
& 0
\end{aligned}-\text { 吾 }
$$

$\bar{\perp} \quad \bar{\omega} \quad \bar{N}=\bar{O}$

$\bar{v}$

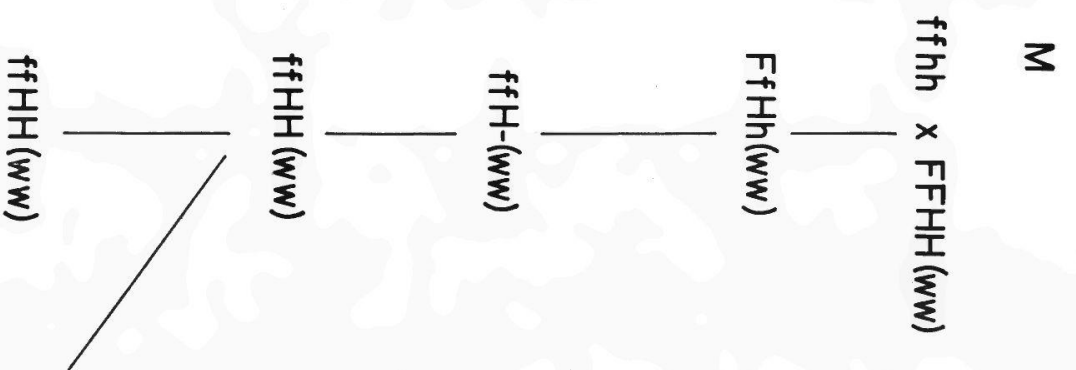

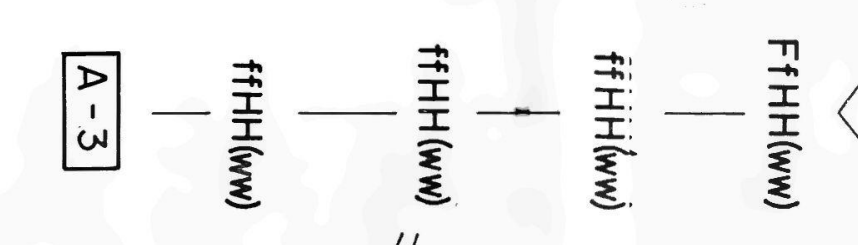<smiles>C1CCCC1</smiles>

I $\stackrel{W}{\rightarrow} \stackrel{\sim}{D}$

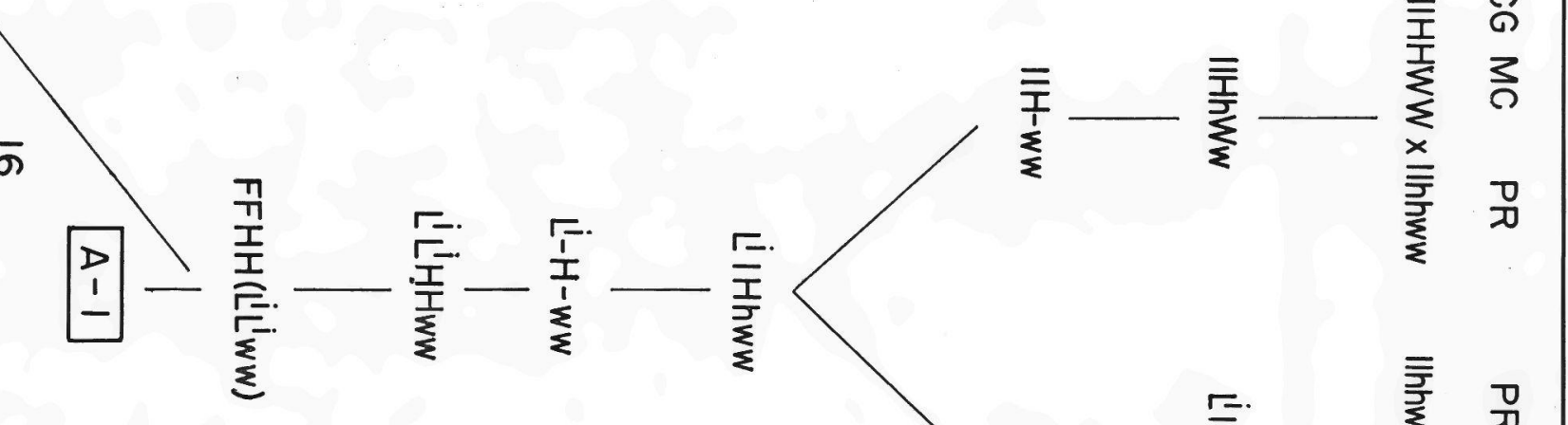

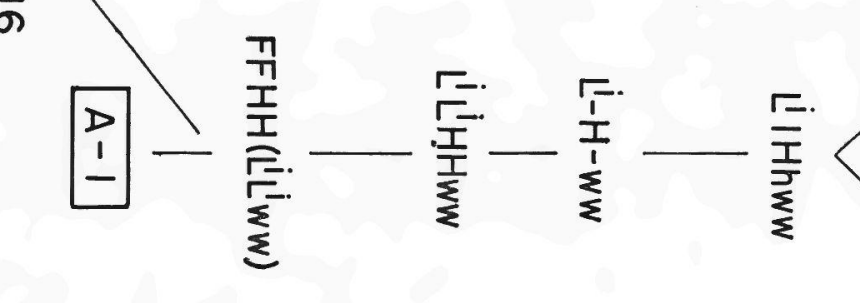

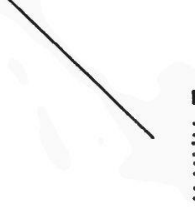

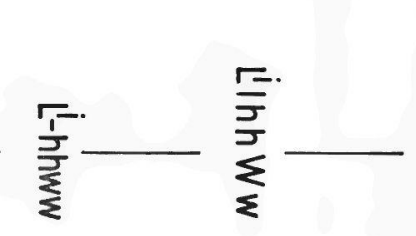

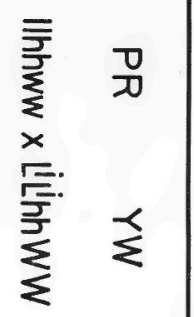

के

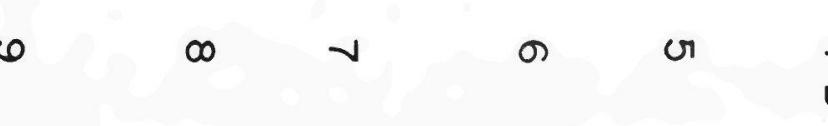

$\begin{array}{lll}b & w \\ b & 1\end{array}$

$\underset{1}{w}$

w

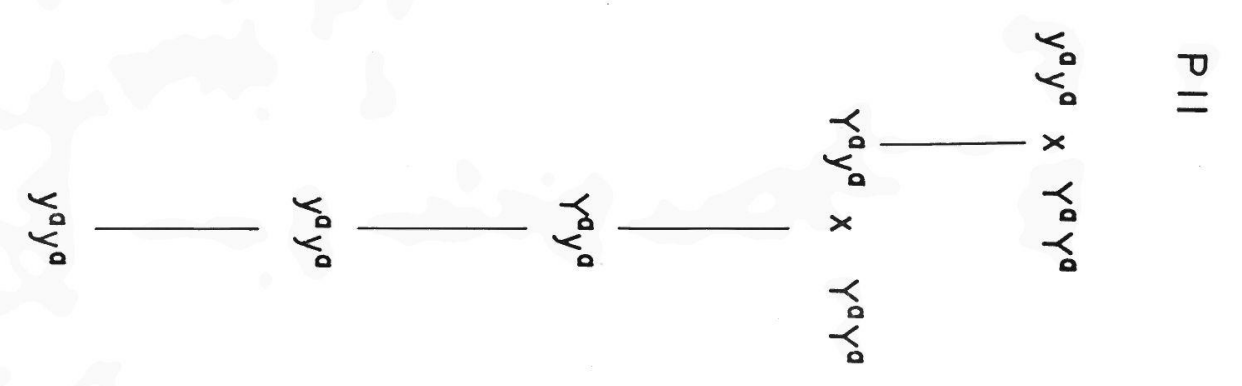

ผ $ก$ ก

$\stackrel{-1}{2}$

กี

N

象

N 
limitada a tão pequena área do tecido inoculado que dificilmente se vê a evidência macroscópica da entrada do vírus. $O$ teste de recuperação do vírus das fôlhas novas e das inoculadas foi sempre negativo. O efeito necrótico resultante ds morte dos tecidos invadidos só é verificado nas nervuras, quando as variedades hipersensíveis são enxertadas sôbre plantas infetadas pelo vírus. Assim sendo, a reação de extrema suscetibilidade comporta-se, nos seus efeitos práticos, como imunidade ao vírus.

O gene responsável por êste caráter foi designado com o símbolo " $\mathrm{H}$ ", que indica a sua principal diagnose, a hipersensibilidade.

\section{2 - RESISTÉNCIA DO PIMENTÃO AO GRUPO W DO VIRUS Y}

O grupo $\mathrm{w}$ foi inicialmente representado pela estirpe $\mathrm{Y}^{\mathrm{w}}$, e com o predomínio da variedade mais severa, $\mathrm{Y}^{\mathrm{f}}$, passou a ser representado por esta última.

A resistência oferecida ao vírus $\mathrm{Y}^{\mathrm{w}}$ pela var. Pôrto Rico Wonder pode ser considerada como uma reação tolerante. O têrmo "tolerância" é empregado para indicar a habilidade de a planta desenvolver-se, apresentando ou não sintomas sensíveis, e produzir satisfatòriamente sob ponto de vista econômico. Esta reação é controlada na var. Pôrto Rico Wonder por um par de genes recessivos que, devido à sua vinculação com a estirpe $w$, foi designado com o símbolo "w". RIOLLANO e col. (22), ao abordarem os resultados referentes à criação da variedade Pôrto Rico Wonder, fizeram menção a "um fator genético simples", sem maiores detalhes. Embora a estirpe $\mathrm{Y}^{\mathrm{w}}$ possa ser diversa daquela para a qual, em Pôrto Rico, a pimenteira Cuaresmeño mostrava-se resistente, o gene "w" aqui descrito deve ser o mesmo fator responsável pela resistência verificada por êsses autores.

A variedade Moura, que se mostrou altamente resistente ao vírus $\mathrm{Y}^{\mathrm{w}}$, não mereceu atenção até que se apresentou resistente ao vírus $Y^{f}$. O tipo de reação é similar ao apresentado pela var. Pôrto Rico Wonder ao vírus $\mathrm{Y}^{\mathrm{w}}$. A resistência da var. Moura ao vírus $\mathrm{Y}^{f}$ é também condicionada por um par de genes recessivos, os quais foram designados com o símbolo " $f$ ", para indicar a resistência à estirpe do mesmo nome. Há, segundo dados obtidos, indicação de alelismo entre os genes " $w$ " e " $f$ ", sendo que o nível de resistência dêste é mais elevado que o do primeiro. 
Nnhuma das estirpes do vírus $\mathrm{Y}$ aqui testadas induziu sintoma sôbre P 11. Tentativas de recuperação do vírus inoculado, tanto das fôlhas novas como das inoculadas mecânicamente, sempre foram negativas. Isto sugere que a reação de $P 11$ ao vírus $\mathrm{Y}$, pelo menos em relação às estirpes inoculadas no presente trabalho, é do tipo imunidade. Os resultados de cruzamentos e a análise genética dos fatôres de imunidade indicam que os genes " $\mathrm{y}^{\mathrm{a}} \mathrm{y}$ " são distintos e independentes dos alelos "ww" e "ff". Este fato esclarece uma dúvida suscitada por COOK (2) quanto à relação entre resistência da var. Pôrto Rico Wonder e a da var. $\mathrm{P} 11$, pois o citado autor não teve a idêntica oportunidade de comparar essas variedades.

A pimenteira $\mathrm{P} 11$ é imune às estirpes do vírus $\mathrm{Y}$, hipersensivel a muitas estirpes do TMV e tolerante a diversas estirpes do virus "etch" do fumo ( 7 ). A seleção unilateral do material feita especificamente para resistência ao vírus $\mathrm{Y}^{f}$ poderia ter redundado na perda de resistência para outros vírus. É admissível também que, no futuro, para um eventual surto de novas variantes do virus $\mathrm{Y}$ mais severas que $\mathrm{Y}^{\mathrm{f}}$ ou outras viroses que se tornarem importantes para o pimentão, o alto nível e largo espectro de resistência que caracterizam Agronômico 8 poderão sofrer limitações.

\section{3 - PREVALENCIA DAS ESTIRPES DO VIRUS $Y$}

Identificação correta dos patógenos prevalecentes é o passo inicial na criação de variedades resistentes. Sendo o teste biológico nas plantas-teste um meio capaz e preciso de distinguir estirpes do vírus, os sintomas desenvolvidos sôbre hospedeira são a indicação tanto da reação daquela variedade à estirpe inoculada como da patogenicidade das estirpes do vírus àquela variedade hospedeira. As estirpes do virus são identificadas pela reação duma série de variedades hospedeiras, enquanto os genes para a reação de resistência ou de suscetibilidade são reconhecidos pela patogenicidade das estirpes inoculadas.

O levantamento das viroses causadas por virus $\mathrm{Y}$ e o reconhecimento das suas estirpes no Estado de São Paulo têm demonstrado a complexidade dêsse problema. Uma das plantas que mais freqüentemente se apresentam afetadas pelo vírus $Y$ é o pimentão. É comum encontrar culturas com $100 \%$ das plantas infetadas por mosaico (11). No entanto, observou-se em Mogi das Cruzes, Estado de São Paulo, que a variedade de pi- 
mentão Casca Dura se mostrava significativamente resistente ao mosaico (18). Tal discrepância só veio a ser esclarecida, quando foi verificada, através de levantamento, a predominância da estirpe $\mathrm{Y}^{\mathrm{n}}$ nas plantações de pimentão em Mogi das Cruzes, para a qual a var. Casca Dura possui resistência. Os levantamentos eîetuados nos anos subseqüentes, entretanto, têm dado a indicação de que o grupo $\mathrm{w}$ tende a prevalecer sôbre o grupo $\mathrm{n}$ do vírus $\mathrm{Y}$, naquela região.

O grupo denominado $\mathrm{w}$ do vírus $\mathrm{Y}$ é infeccioso, entre outras culturas, ao tomateiro e pimentāo, mostrando extensa distribuição geográfica. A estirpe $\mathrm{Y}^{\mathrm{w}}$ era representativa do grupo e mais largamente disseminada até alguns anos passados. $O$ surto da estirpe $\mathrm{Y}^{\mathrm{f}}$ se deve provàvelmente a um evento conseqüente a uma mutação ocorrida, há tempos, no sentido de maior virulência, mas que sòmente veio à tona na ocasião do ensaio de competição das variedades de pimentão, no campo, onde os genes "w" e "f" tiveram oportunidade de ser confrontados. As observações anteriores, segundo as quais as variedades Pôrto Rico Wonder e Mogi das Cruzes, e também a variedade de tomateiro Santa Cruz, eram mais brandamente afetadas por vírus $\mathrm{Y}$, indicam a virulência mais acentuada da nova variante. Apesar disso, não seria totalmente inválida a tese de que $\mathrm{o}$ isolado de vírus $\mathrm{Y}^{\mathrm{w}}$ usado nas investigações se havia tornado enfraquecido e menos virulento à var. Pôrto Rico Wonđer, como conseqüência de ter-se mantido na planta de fumo durante longo tempo.

Da mesma maneira que se disseminou a estirpe $\mathrm{Y}^{f}$ em larga escala, seria admissível a nova mudança no quadro das estirpes do vírus $Y$, independente de quaisquer influências por parte das variedades cultivadas. Mas, a introduçāo e a expansāo đas variedades do pimentāo e do tomateiro resistentes ao vírus $\mathrm{Y}^{\mathrm{f}}$, que ocorrerāo dentro em breve, poderão influenciar e alterar a dinâmica da variabilidade do vírus na área de seus cultivos mais intensos.

\section{4 - TESTES DE MATERIAIS RESISTENTES}

O ambiente influencia a resistência das plantas a moléstias. Porém, mais do que o contrôle de condiçōes ambientes, o teste de resistência efetuado dentro da casa de vegetação, com a inoculação artificial devidamente organizada, permite realizar contrôle sôbre o inóculo por meio de purificação das estirpes. 
Supondo haver dupla infecção ou contaminação do vírus $\mathrm{Y}^{\mathrm{w}}$ com $\mathrm{Y}^{\mathrm{n}}$, a mistura de ambos, tão pròximamente relacionados, poderá produzir resultados ambiguos num teste em que a resistência a um vírus pode ser mascarada por outro vírus. Esta situação é apresentada no quadro 11.

QUADRo 11. - Reação das variedades Casca Dura e Pôrto Rico Wonder e das progênies derivadas do cruzamento entre estas, quando inoculadas com os vírus $\mathrm{Yn}$, $\mathrm{Yw}$ e a mistura dos dois vírus

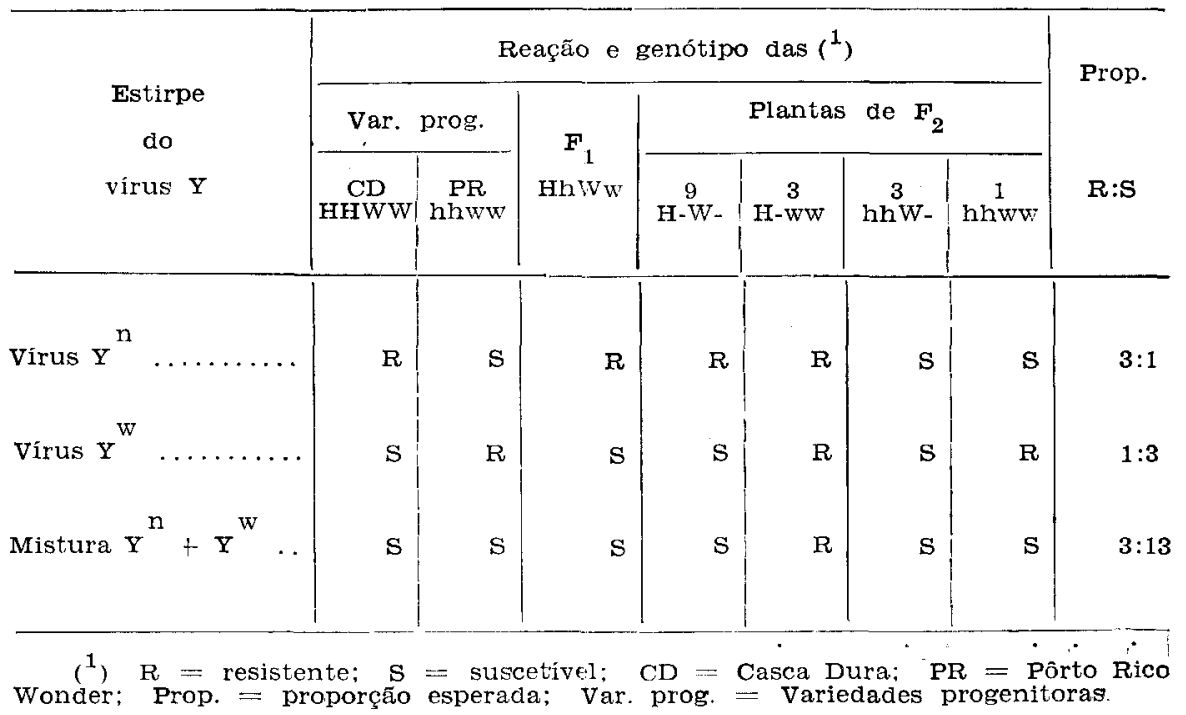

O quadro demonstra a dificuldade que seria encontrada na procura de fontes de resistência e na análise dos fatôres genéticos, caso se trabalhasse com inóculos representados por complexos de estirpes e não com os componentes separados.

Nos experimentos de campo pode ocorrer amiúde êsse tipo de mascaramento de resistência, se mais de uma estirpe estiver presente. Porém, desde que êste fenômeno é compreendido, a exposição dos materiais resistentes à infecção natural é de suma importância para estudar a frequiência de determinadas estirpes, mudança de prevalência das estirpes e a ação sinérgica que porventura vários fatôres genéticos de resistência reunidos possam propiciar. Ademais, nos experimentos de campo, podem ser observados os tipos de resistência comumente conhecidos como "resistência de campo", "escape" etc.,o que poderá caracterizar melhor as plantas resistentes. 


\section{5 - INCORPORAÇÃO DOS FATÔRES GENÉTICOS}

Em melhoramento para resistência a moléstias, a seleção para qualidades econômicas pode ser tão trabalhosa quanto à incorporação de fatôres de resistência. No trabalho em que quatro ou mais variedades diferentes de pimentão compuzeram linhagens diversas, a seleção para o formato cônico alongado dos frutos encontrou muita dificuldade, devido à heterogeneidade das variedades progenitoras. Assim, traços retorcidos que caracterizam a var. Mogi das Cruzes permaneceram marcantes, enquanto nas progênies derivadas do cruzamento entre Pôrto Rico Wonder e P 11 foi notada forte feição da pimenteira. Em compensação, a seleção para o aumento do tamanho de frutos, nas progênies de $\mathrm{P} 11$ retrocruzadas com as variedades de pimentão, produziu resultados surpreendentemente favoráveis. A determinação da presença do ardume nessas progênies foi feita por teste gustativo e não por métođo de análise química $(33,34)$.

\section{6 - UTILIZAÇÃO DAS VARIEDADES RESISTENTES}

Seria desnecessário enumerar os benefícios provindos do emprêgo de variedades resistentes a moléstias e pragas. Porém, no caso do pimentão resistente ao mosaico causado por vírus $Y$, merece especial destaque o fato de esta moléstia, além de ser a virose mais importante para o próprio pimentão, constituir-se numa das mais destrutivas moléstias de vírus do tomateiro. $\mathrm{E}$, como o pulgão Myzus persicae se reproduz preferencialmente no pimentão, o vírus $\mathrm{Y}$ é disseminado fàcilmente de uma cultura para outra, reciprocamente. Por isso, como medida indireta de contrôle da "risca do tomateiro", a virtual imunidade incorporada por pimentão Agronômico 7 e por Agronômico 8 será de inestimável valor para a lavoura de hortaliças, pois eliminará uma das principais fontes do vírus $\mathrm{Y}$.

Considerando-se que qualidades comerciais e produção são essenciais numa variedade cultivada, a criação da variedade Agronômico 8 foi dirigida no sentido de obter qualidades comerciais do tipo Casca Dura, que presentemente é de maior aceitaçāo no mercado de São Paulo. Agronômico 7, por sua vez, mantém outro padrão comercial do tipo California Wonder. Quanto à produção, pode-se afirmar que, nas regiões onde ocorre o mosaico, a resistência representa um fator decisivo que assegura a produção. Como uma variedade cultivada, Agronômico 8 apresenta produção maior que as variedades comuns. 
As novas variedades Agronômico 7 e Agronômico 8, de produtividade assegurada por diversos fatôres de resistência às moléstias de vírus, e que apresentam qualidades econômicas desejáveis, satisfazem plenamente a exigência e a necessidade do atual mercado produtor e consumidor.

BREEDING SWEET PEPPER VARIETIES FOR RESISTANCE TO MOSAIC

\section{SUMMARY}

A highly prevalent type of mosaic that induces heavey losses to sweet pepper (Capsicum annuum L.) plantings in São Paulo and other neighboring states is caused by two groups of the potato virus $\mathrm{Y}$ complex, designated as $n$ and $w$. Group $n$ is represented by strain $Y n$, group $w$ by strains $\mathrm{Yw}$ and $\mathrm{Yf}$.

Screening tests with 45 sweet pepper varieties and 46 others of the pungent type, belonging to several species of Capsicum, were carried out in the greenhouse and in the field to detect resistance to mosaic.

A hypersensitive type of resistance to $\mathrm{Yn}$ was found in the sweet pepper varieties Mogi-das-Cruzes and Casca-Dura. Porto Rico Wonder was tolerant to $\mathrm{Yw}$, but not so to a related strain, $\mathrm{Yf}$. A sweet pepper variety called Moura was highly tolerant to $\mathrm{Y}^{f}$. A variety known as P 11 (P.I. 264281) (Capsicum annuum) was found to be immune to all $\mathrm{Y}$ virus strains tested. The pungent types SA 112 (C. pubescens), I-30771 and I-30772 (C. pendulum) also behaved immune to $\mathrm{Y}$ virus strains, but were not used as sources of resistance because they are not compatible with C. annuum.

Inheritance studies disclosed the existence of 3 new pairs of genes responsible for the various types of resistant reactions to strains of the potato $\mathrm{Y}$ virus in Capsicum annuum. They can be described as follows:

Gene " $\mathrm{H}$ " is a dominant allele found in Mogi-das-Cruzes and Casca-Dura, that conditions hypersensitivity to $\mathrm{Yn}$. Gene " $\mathrm{W}$ " is a recessive factor that controls tolerance of Porto Rico Wonder to strains of $\mathrm{Yw}$. Gene " $\mathrm{f}$ " is a recessive factor that conditions tolerance to $\mathrm{Y}^{f}$ in the sweet pepper variety Moura. Gene " $f$ " behaves as an allele of " $w$ ", affording a higher level of tolerance to strains of the $\mathrm{Y}$ virus complex.

The immunity to various strains of the $\mathrm{Y}$ virus complex found in Florida in P 11 (P.I. 264281) by COOK \& ANDERSON ( $y$ ), and attributed by these investigators to a pair of recessive genes "yaya", was also verified for strains of the $\mathrm{Y}$ virus complex present in São Paulo. 
The sweet pepper varieties Yolo Wonder and All Big were introduced in the breeding program because they carry the partially dominant genes " $\mathrm{LiLi}$ " (17) that controls resistance to tobacco mosaic virus in pepper.

Early in the development of the present breeding program, the genes "HH", "Ww" and "LiLi" were combined in several improved lines, but appearence of a new strain $\mathrm{Y}^{f}$ showed the need of a higher resistance level than that present in these tri-hybrid lines. The incorporation of the Moura type of tolerance due to genes "ff" permitted the development of commercial lines highly tolerant to strains of the $\mathrm{Y}$ virus complex.

The immunity to strains of the $Y$ virus complex from $P$ 11, due to genes "yaya", was incorporated to sweet pepper genotypes already possessing the other types of resistance to $\mathrm{Y}$ mosaic and to TMV. This resulted in two new groups of sweet pepper varieties that are immune to all strains of the $\mathrm{Y}$ complex so far tested, resistant to TMV, high yielding, and with good commercial characteristics: Agronomico 7 has fruits of the blocky type (California Wonder type) and Agronomico 8 has tapering, elongated fruits (Casca-Dura type).

\section{LITERA TURA CHADA}

1. ANDERSON, C. W. \& CORBETT, M. K. Virus diseases of peppers in Central Florida. Survey results. 1955. Pl. Dis. Reptr, 41:143-147, 1957.

2. COOK, A. A. Genetics of resistance in Capsicum annuum to two virus diseases. Phytopathology 50:364-367, 1960.

3. A mutation for resistance to potato virus $\mathrm{Y}$ in pepper. Phytopathology 51:550-552, 1961.

4. - Isolation of a mutant strain of potato $\mathrm{Y}$ virus. Pl. Dis. Reptr, 46:569, 1962.

5. Genetics of respense in pepper to three strains of potato virus $\mathrm{Y}$. Phytopathology 53:720-722, 1963.

6. - - Dominant resistance to tobacco mosaic virus in an exotic pepper. Pl. Dis. Reptr, 47:783-786, 1963.

7 \& ANDERSON, C. W. Multiple virus disease resistance in a strain of Capsicum annuum. Phytopathology 49:198-201, 1959.

8.

\& - Inheritance of resistance to potato virus $\mathrm{Y}$ derived from two strains of Capsicum annuum. Phytopathology 50:73-75, 1960.

9. COOK, M. T. Annual Report. Ins. Exp. Sta., Dept. of Agri. and Labor of Puerto Rico: Fiscal Year 1927-1928. 65p. 
10. Costa, A. S. \& ALVES, S. Mosaico do pimentão. Bragantia $10: 95-96,1950$.

11. - CARVALHO, A. M. B. \& KITAJIMA, E. W. Risca do tomateiro em São Paulo, causada por estirpe do vírus Y. Bragantia 19:1111-1128, 1960.

12. DALE, W. T. Sap-transmissible mosaic disease of solanaceous crops in Trinidad. Ann. appl. Biol. 41:240-247, 1954.

13. HAYES, H. K.; IMMER, F. R. \& SMITH, D. C. Methods of plant breeding. 2nd ed. New York, MCGraw-Hill Book Co. 1955. $551 \mathrm{p}$.

14. HEISER,JR., C. B. \& SMITH, P. G. Observations on another species of cultivated pepper, Capsicum pubescens R. \& P. Proc. Am. Soc. hort. Sci. 52:331-335, 1948.

15. ___ \& $\quad$ _ _ C The cultivated Capsicum peppers. Econ. Bot. 7:214-227, 1953.

16. HOLMES, F. O. Inheritance of ability to localize tobacco-mosaic virus. Phytopatology 24:984-1002, 1934.

17. In_ Inheritance of resistance to tobacco mosaic disease in the pepper. Phytopatology 27:637-642, 1937.

18. IKUTA. H. \& DIAS, M. S. Ensaio de variedades de pimentão. III.a Reunião Anual da Sociedade de Olericultura do Brasil, 1963. (Mimeografado)

19. Kitajima, E. W.; Carvalho, A. M. B. \& Costa, A. S. Microscopia electrônica de estirpes do vírus $\mathrm{Y}$ da batatinha que ocorrem em São Paulo. Bragantia 21:755-763, 1962.

20. LIPPERT, L. F.; BERGH, B. O. \& SMITH, P. G. Genes list for the pepper. Jour. Hered. 56:30-34, 1965.

21. PÉREZ, J. E. \& ADSUAR, J. Antigenic relationship between Puerto Rican pepper mosaic virus and a strain of potato virus $\mathrm{Y}$. J. Agric. Univ. P. Rico 39:165-167, 1955.

22. RIOLLANO, A.; ADSUAR, J. \& RODRIGUES, A. Breeding peppers resistant to a Puerto Rican type of mosaic. Proc. Am. Soc. hort. Sci. 51:415-416, 1948.

23. ROQUE, A. \& ADSUAR, J. Studies on the mosaic of peppers (Capsicum frutescens) in Puerto Rico. J. Agric. Univ. P. Rico 25:40-50, 1941.

24. SIMMONDS, N. W. \& HARRISON, E. The genetics of reaction to pepper vein-banding virus. Genetics 44:1281-1289, 1959.

25. SIMONS, J. N. The pepper veinbanding mosaic in the Everglades area of South Florida. Phytopatology 46:53-57, 1956.

26. Potato virus $Y$ appears in additional areas of pepper and tomato production in South Florida. Pl. Dis. Reptr. 43:710-711, 1959. infection with potato virus $\mathrm{Y}$. Phytopatology 56:1370-1375, 1966. 
28. SIMONS, J. N.; CONOVER, R. A. \& WALTER, J. M. Correlation of occurrence of potato virus $\mathrm{Y}$ with areas of potato production in Florida. Pl. Dis. Reptr 40:531-533, 1956.

29. SMITH, P. G. \& HEISER, JR., C. B. Taxonomic and genetic studies on the cultivated peppers, Capsicum annuum $\mathrm{L}$. and Capsicum frutescens L. Am. J. Bot. 38:362-368, 1951.

30. \& —_. Breeding behavior of cultivated peppers. Proc. Am. Soc. hort. Sci. 70:286-290, 1957.

31. Taxonomy of Capsicum sinense Jacq. and the geographic distribution of the cultivated Capsicum species. Bull. Torrey bot. Club 84:413-420, 1957.

32. ; RICK, C. M. \& HEISER JR., C. B. Capsicum pendulum Willd., another cultivated pepper from South America. Proc. Am. Soc. hort. Sci. 57:339-342, 1951.

33. TING, S. V.\& BARRONS, K. B. A chemical test for pungency in pepper. Proc. Am. Soc. hort. Sci. 40:504-508, 1942.

34. VAN BLARICON. L. O. \& MARTIN, J. A. Permanent standards for chemical test for pungency in peppers. Proc. Am. Soc. hort. Sci. 50:297-298, 1947. 

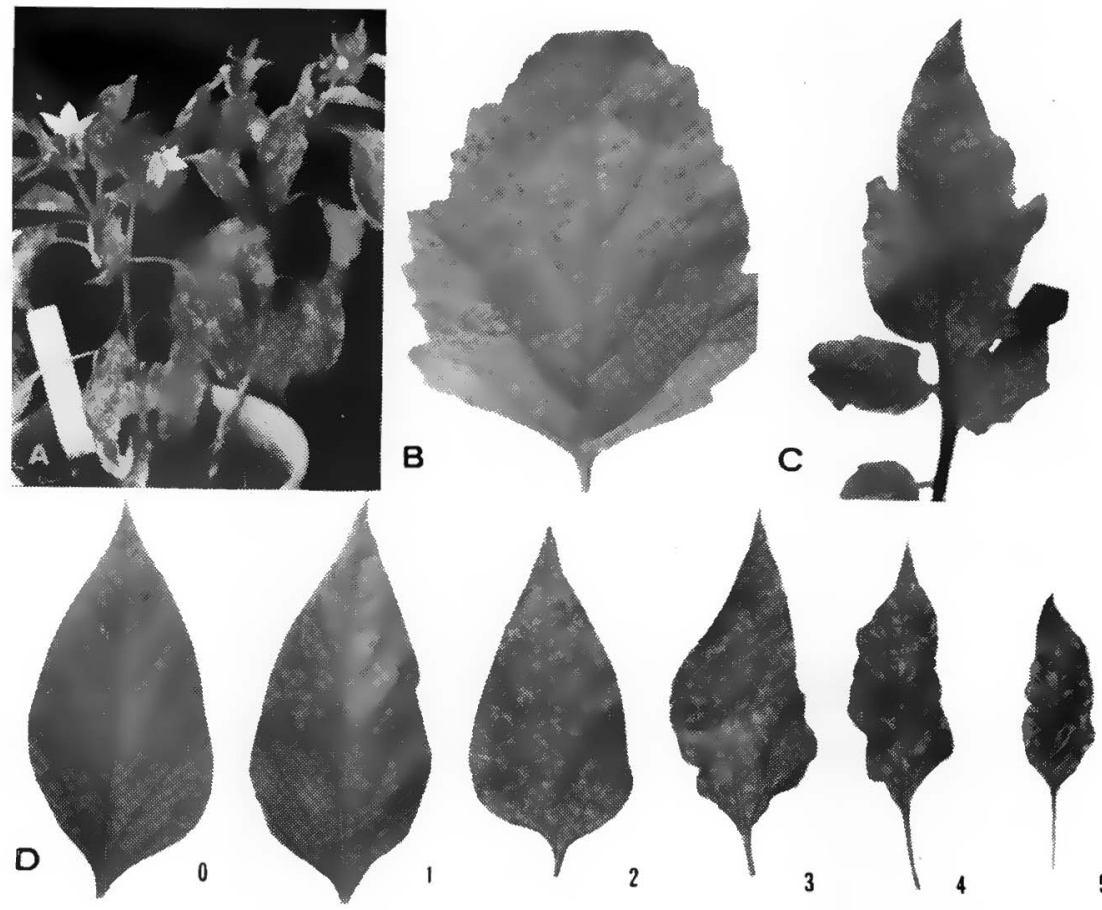

Reação provocada por virus $\mathrm{Y}$ em diversas hospedeiras: 1-A. Aspecto da planta de pimentão afetada por mosaico: 1-B. Lesões locais produzidas por virus $\mathrm{Y}^{\mathrm{n}}$ sôbre fôlha de Nicandra; 1-C. Necrose (risca) causada por vírus $\mathrm{Y}^{\mathrm{f}}$ no tomateiro var. Santa Cruz; 1-D. Graus de reação ao vírus $\mathbf{Y}$ nas variedades de pimentão: 0 - Imune; 1 - Resistente; 2 - Moderad. resist.; 3 - Moderad. suscetível; 4 - Muito suscetível; 5 - Extrem. suscetível. 


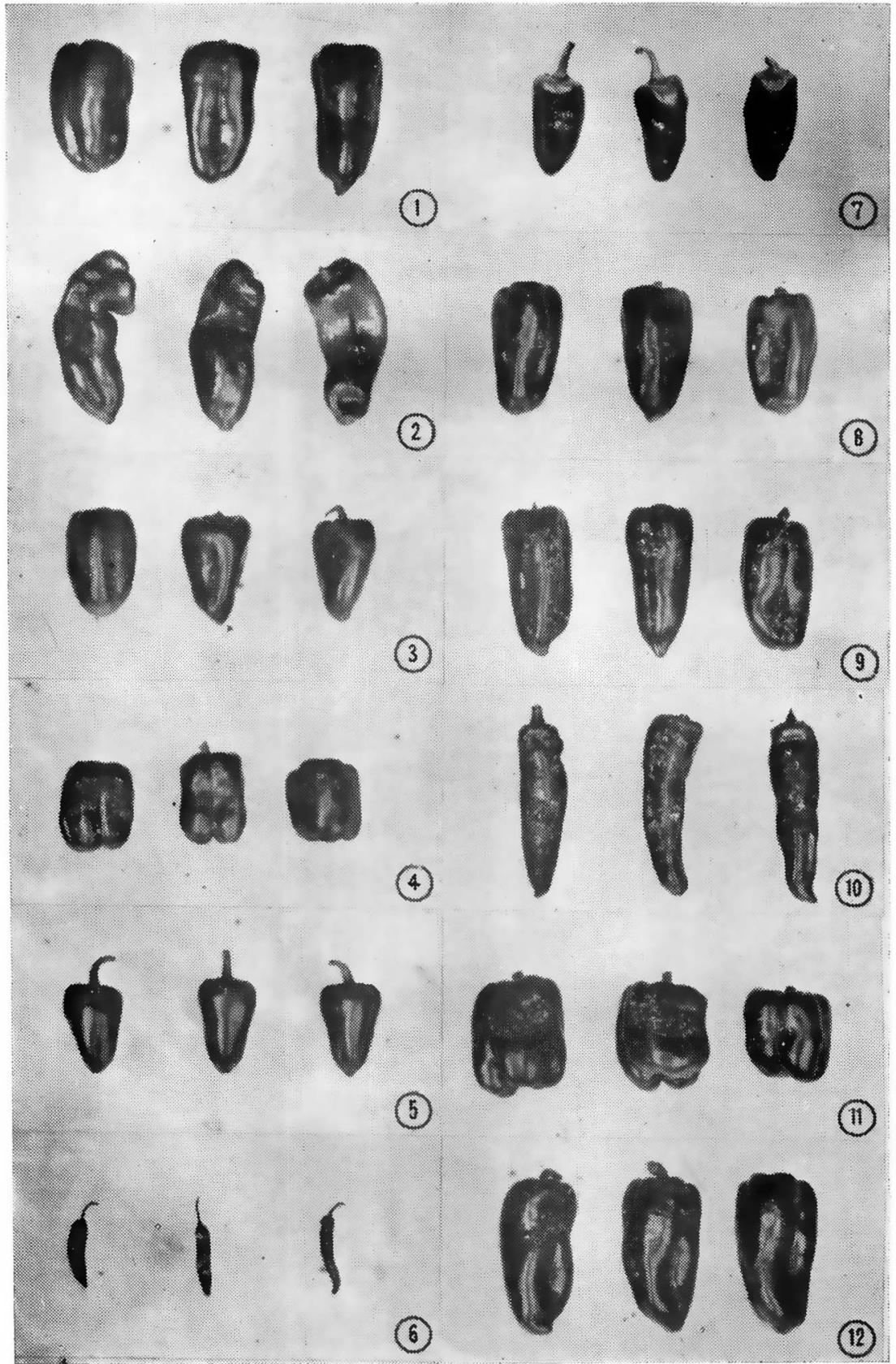

Frutos de variedades de pimentão e pimenteira estudadas e seus hibridos resistentes ao mosiaico (Aumerio aprox. 0,12 X). 1 - Casca Dura: 2 - Mogi das Cruzes; 3 - Pôrto Rico Wonder; 4 - Yolo Wonder; 5 - Moura; 6 - P 11 (P. I. 265281); 7 - Cruzamento entre P 11 e Pôrto Rico Wonder; 8 - Agronômico 2; 9 - Agronômico 3; 10 - Agro. nômico 4; 11 - Agronômico 7; 12 - Agronômico 8. 